\title{
DEALING WITH DEALERS: SOVEREIGN 2017 CDS COMOVEMENTS
}

Miguel Antón, Sergio Mayordomo.

and Maria Ro diguez-Moreno.

Documentos de Trabajo.

N. 1723

\section{BANCODE ESPAÑA}

Eurosistema

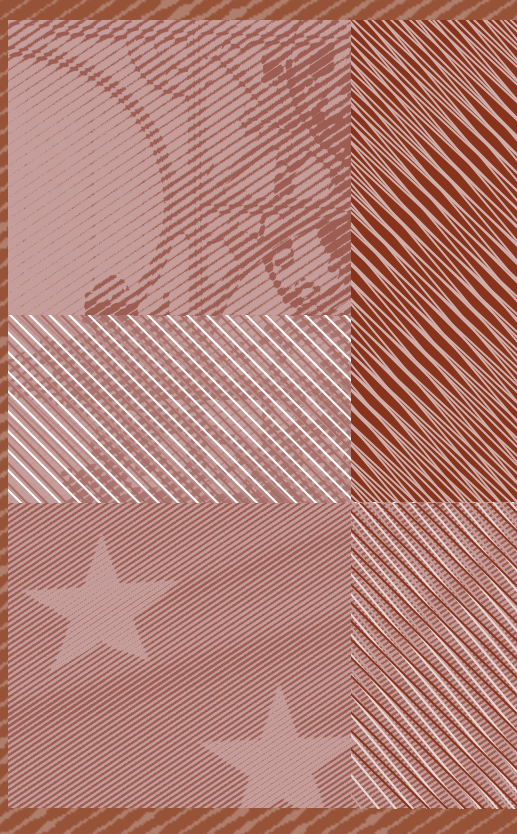


DEALING WITH DEALERS: SOVEREIGN CDS COMOVEMENTS 
DEALING WITH DEALERS: SOVEREIGN CDS COMOVEMENTS ${ }^{(*)}$

\section{Miguel Antón}

IESE BUSINESS SCHOOL

\section{Sergio Mayordomo ${ }^{(*)}$ and María Rodríguez-Moreno}

BANCO DE ESPAÑA

(*) Antón: Department of Finance, IESE Business School, Av. Pearson 21, 08034 Barcelona, Spain. Email: manton@iese.edu. Rodríguez-Moreno: Department of Financial Stability, C/ Alcalá 48, 28014 Madrid, Spain. Email: maria.rodriguezmoreno@bde.es. The views expressed in this paper are those of the authors and do not necessarily coincide with those of the Banco de España and the Eurosystem. This paper was partially drafted and circulated while Sergio Mayordomo was at the Spanish Securities and Exchange Commission under the title "Intraday credit risk spillovers in the European sovereign CDS market". We are very grateful for comments from Oriol Aspachs, Ana Babus, Roberto Blanco, Robert Engle, Xavier Freixas, Nicolae Garleanu, Ricardo Gimeno, Mireia Giné, Jordi Gual, Sven Klingler, Germán López-Espinosa, Javier Mencía, Antonio Moreno, Paolo Pasquariello, Fulvio Pegoraro, Stefano Puddu, Tano Santos, Pedro Serrano, Neal Stoughton, Davide Tomio, Carles Vergara, Luis Viceira, Xavier Vives, PierreOlivier Weill, Haoxiang Zhu, as well as participants at the 7th Financial Risk International Forum in Paris, the Arne Ryde Workshop in Financial Economics in Lund 2014, the First International Conference on Sovereign Bond Markets in Tokyo 2014, and seminar participants at IESE Lunchtime workshop, Leicester University, CaixaBank, Université de Neuchâtel, and Banco de España. The authors acknowledge financial support of the Cátedra UAM-Accenture and the Fundación de Estudios Financieros in the form of research prizes. Miguel Antón acknowledges the financial support of the European Commission, Marie Curie CIG (GA no. 303990), and the financial support of the Spanish Ministry of Economy and Competitiveness (Project ref: ECO2011-29533) at Public-Private Sector Research Center IESE Business School, University of Navarra, Spain.

$\left.{ }^{\star *}\right)$ Corresponding author. Sergio Mayordomo: Banco de España, ADG Economics and Research, C/ Alcalá 48, 28014 Madrid, Spain. Email: sergio.mayordomo@bde.es. Phone: +34 917088149. 
The Working Paper Series seeks to disseminate original research in economics and finance. All papers have been anonymously refereed. By publishing these papers, the Banco de España aims to contribute to economic analysis and, in particular, to knowledge of the Spanish economy and its international environment.

The opinions and analyses in the Working Paper Series are the responsibility of the authors and, therefore, do not necessarily coincide with those of the Banco de España or the Eurosystem.

The Banco de España disseminates its main reports and most of its publications via the Internet at the following website: http://www.bde.es.

Reproduction for educational and non-commercial purposes is permitted provided that the source is acknowledged.

(c) BANCO DE ESPAÑA, Madrid, 2017

ISSN: 1579-8666 (on line) 


\section{Abstract}

We show that sovereign CDS that have common dealers tend to be more correlated, especially when the dealers display similar quoting activity in those contracts over time. This commonality in dealers' activity is a powerful driver of CDS comovements, over and above fundamental similarities between countries, including default, liquidity, and macro factors. We posit that the mechanism causing the excess correlation is the buying pressure faced by CDS dealers for credit enhancements and regulatory capital reliefs. An instrumental variable analysis confirms that our findings are indeed rooted in a causal relationship.

Keywords: sovereign CDS, comovements, commonalities, dealers.

JEL Classification: G12, G14. 


\section{Resumen}

En este estudio se muestra que los CDS soberanos que comparten dealers tienden a estar más correlacionados, especialmente cuando estos dealers presentan una actividad similar en la frecuencia de sus cotizaciones de dichos CDS. Este comportamiento común en la actividad de los dealers es uno de los principales causantes de la covariación de los precios de los CDS soberanos, más allá de las similitudes en los fundamentales entre países tales como riesgo de fallido, liquidez y factores macroeconómicos. El mecanismo que causa este exceso de correlación es la presión de compra a la que se enfrentan los dealers, en su mayoría bancos, para la mejora de la calidad crediticia de su cartera y/o del capital regulatorio. Un análisis de variables instrumentales confirma que la evidencia anterior tiene una relación causal.

Palabras clave: CDS soberanos, dealers, covariación.

Códigos JEL: G12, G14. 
Asset returns may comove beyond what can be expected from their fundamentals due to the existence of frictions or anomalies. In this paper, we empirically investigate why sovereign Credit Default Swap (CDS) spreads comove 'too' much, or more than what one might expect based on economic similarities between countries. The use of a unique dataset with dealer-level intraday quotes helps us better understand the impact of dealers' activity on CDS comovements. Pairs of sovereign CDS that share common dealers, specifically when those dealers display similar activity over time, tend to be more correlated, all else equal. We measure this common dealership, which we label Commonality in Quotes, as the correlation between the number of daily quotes reported by a given dealer to each of the two countries in a pair.

Our main finding is that the Commonality in Quotes is a powerful driver of CDS abnormal return correlation, controlling for country similarities in default, liquidity, and macro variables. The effect is statistically and economically significant. A one standard deviation increase in the Commonality in Quotes would lead to an increase equivalent to $17.3 \%$ of the average CDS abnormal return correlation, which we label CDS excess correlation. In fact, the economic impact of the Commonality in Quotes is stronger than that attributable to the remaining country-pair specific and global factors employed as explanatory variables.

We posit that the mechanism causing the CDS excess correlation is the buying pressure faced by CDS dealers. Specifically, we conjecture that the common demand on a given pair of sovereign CDS is explained by the dealers' urgency to buy protection in order to mitigate the credit risk in their portfolios and/or to lower regulatory capital requirements, especially in banks (Yorulmazer, 2013; Klingler and Lando, 2014; Hasan and Wu, 2016; Shan, Tang, and Yan, 2016; and Augustin, Sokolovski, Subrahmanyam, and Tomio, 2017). Sovereign CDS are appropriate instruments to hedge direct exposures to sovereign debt or hedge other assets whose value is correlated with the creditworthiness of the sovereign as banking or utility sectors (see April 2013 World Economic Outlook, IMF). Additionally, when a bank acquires a CDS against a risky investment, the bank can hold less capital against such investment. In particular, Hasan and Wu (2016) document that, among the potential uses of CDS by banks, they principally use CDS because of their benefits in terms of capital reliefs and credit enhancement. In fact, as stated by Yorulmazer (2013), AIG claimed that $72 \%$ of the notional amounts of CDS sold by AIG as of December 2007 were used by European and other banks for capital relief purposes. This willingness to trade exerts a pressure, increasing CDS premia in a way that is not necessarily related to the fundamentals of those CDS. As a consequence, when the dealer is active enough, and experiences this buying pressure in the CDS of two different countries, it will induce an extra or non-fundamental correlation between the CDS of those countries. If the mechanism is a fundamental one, through information, then there should be no difference between the strength of the effect associated to dealers facing buying pressure and the others. Thus, the exclusive effect of the former type of dealers is consistent with a non-fundamental friction in the CDS market originated by the dealers. It turns out that the CDS market is especially prone to having relative large players because it is dominated by the so called G14 dealers, who are the largest banks acting as derivatives dealers worldwide and hold roughly $90 \%$ of the CDS notional amount 
(Mengle, 2010). ${ }^{1}$ In fact, we find that our Commonality in Quotes variable explains CDS excess comovement especially when most active dealers face buying pressure.

The relationship between Commonality in Quotes and CDS excess correlation can also move in the opposite direction, so endogeneity could be a concern. For example, dealers could choose to provide more quotes to those pairs of countries whose CDS prices are more correlated. We deal with this issue with an instrumental variable approach. We use as instrument for dealers' buying pressure the average Tier 1 capital ratio of a large group of international banks that are potential participants in the CDS market. The banks employed to obtain the average quarterly Tier 1 for a given pair of countries are those for which the sovereign debt of these countries has positive risk weights. To ensure the potential use of CDS for capital reliefs, we use banks in countries with a positive exposure to the official sectors of both countries forming the pair. Finally, to make the instrument as exogenous as possible, we use banks without headquarters or subsidiaries in any of the two countries forming the pair. The motivation for the use of this instrumental variable relies on the use of CDS by banks as credit risk mitigants to reduce the capital requirements for existing exposures. In the context of the Basel II Accord, banks should satisfy a minimum capital requirement defined as the ratio between core equity (or Tier 1 capital) and risk weighted assets (RWA). Thus, the demand on a given pair of sovereign CDS would be associated with the banks' Tier 1 capital ratio and so, with the participants in the CDS market; but not with the ex-ante CDS comovement. In fact, the results of the first stage of the instrumental variable approach confirm that improvements in the average Tier 1 capital ratio are related to an active control of the RWA, through the demand of sovereign CDS for those countries whose bonds have positive risk weights. It supports the validity of the mechanism addressed in this paper of how dealers affect pricing, because otherwise we would not necessarily see a correlation of our specific instrument with our Commonality in Quotes variable. The results obtained from the endogeneity analysis, and from several extensions and additional tests, confirm that our finding is indeed rooted in a causal relationship between Commonality in Quotes and CDS excess comovement.

Our findings link to two different strands of the literature. It first builds on a series of papers documenting an increasing trend in the comovements between the CDS spreads of the European Monetary Union (EMU) countries during the recent crisis (i.e., Alter and Beyer (2014), Broto and Pérez-Quirós (2015), Caporin, Pelizzon, Ravazzolo, and Rigobon (2013), or Kalbaska and Gatkowski (2012), among others). However, little is known about the effect of dealers' liquidity provision on CDS price comovements. We contribute to this strand of the literature using information at the dealer level to study how their activity helps improve the explanatory power of such comovements. The importance of dealers' activity in the CDS market is remarkable. Robert Pickel, CEO of ISDA, in his testimony before Congress on March 10, 2009, stated that $86 \%$ of the Depository Trust \& Clearing Corporation (DTCC) trades were dealer-to-dealer.

Secondly, our findings build on a series of papers related to the broader area of market frictions in financial markets. It is specifically linked to those papers documenting that market frictions make prices deviate from fundamentals or comove beyond fundamentals (see Barberis, Shleifer, and Wurgler (2005), and others). Our paper also relates to the stream of the

1. The G14 dealers comprise Bank of America-Merrill Lynch, Barclays Capital, BNP Paribas, Citi, Credit Suisse, Deutsche Bank, Goldman Sachs, HSBC, JP Morgan, Morgan Stanley, RBS, Societe Generale, UBS and Wells Fargo Bank. These dealers are the most active global derivatives dealers and are known as the G14 (see, for instance, ISDA Research Notes (2010) on the Concentration of OTC Derivatives among Major Dealers). 
literature that investigates the relationship between common dealership and return commonality. In this vein, Pasquariello and Vega (2015) find that cross-price impact is greater among stocks dealt by the same specialist. ${ }^{2}$ Although there is a well-established body of studies postulating and providing evidence of excess comovement on stock prices, there is scarce evidence on this phenomenon in the CDS market. The analysis of excess comovements in an Over-the-Counter (OTC) market, as the sovereign CDS market, is of special interest for several reasons. First, according to Lin and Howe (1990), the market microstructure of the OTC market is different from that of organized exchanges. According to those authors, the multiplicity of market makers in the OTC market may allow insiders to more carefully conceal their trading. Second, sovereign CDS have become prevalent tools for risk analysis, and in fact, they are used in deriving estimates of default risk and in the calculation of regulatory and economic capital. Thus, understanding the forces in play in the CDS market seems of special relevance. In fact, Grossman and Hansen (2010) find that CDS are poor indicators of default in the financial crisis, given that they are influenced by many factors beyond the fundamental credit positions of countries concerned.

Our analysis focuses on the effect of friction-based trading on CDS price comovements. Some recent papers have studied the price impact of intraday CDS transactions in the presence of trading frictions. Shachar (2013) examines the role of liquidity provision by dealers in the CDS market and finds that order imbalances of end-users have a significant impact on price, which depends on the sign of the dealers' inventory. Tang and Yan (2015) also document that, besides the traditional determinants, CDS spreads are affected by supply-demand imbalance being the effect of excess demand of a higher magnitude. GehdeTrapp, Gündüz, and Nasev (2015) show that CDS traders adjust their prices to the order flows they observe, with the adjustment of the premium growing stronger as inventory risk increases. Siriwardane (2014) measures CDS sellers' capacity to supply CDS and documents that dealers' risk-bearing capacities affect CDS prices. ${ }^{3}$

We contribute to the above mentioned literature by documenting a cross-securities price pressure derived from non-fundamental-based demand channeled through the use of sovereign CDS by banks to reduce portfolio credit risk and/or to lower regulatory capital requirements. There is little evidence of this cross-asset price pressure in the sovereign CDS market. According to data provided by DTCC, sovereign CDS were among the top traded single-name contracts, including corporates, in terms of the net notional amount. Moreover, sovereign and corporate CDS contracts are known to be different (see Vogel, Bannier, and Heidorn (2013); and European Central Bank (ECB), (2009)).

Summarizing, the use of a unique dataset with dealer-level intraday quotes enables us to provide new evidence on the role of non-fundamental factors in explaining sovereign CDS comovements. Taken together, our results are consistent with the CDS premia containing a non-default-related component. This willingness towards a joint buy of sovereign CDS strongly contributes to causing comovement across their credit spreads. The economic magnitude of this non-fundamental-based trading is not negligible. This effect should be accounted for before using CDS as a measure of risk and/or contagion as recommended by some policy

2. The comovement of securities' liquidity due to the common dealership role of dealers as liquidity providers for more than one security has also been documented for the case of stocks (Coughenour and Saad, 2004) and bonds (Gissler, 2017). Coughenour and Saad (2004) show that individual stock liquidity covaries with the liquidity of other stocks handled by the same specialist firm. Gissler (2017) shows that liquidity of single U.S. corporate bonds moves together with other bonds' liquidity traded by the same dealers.

3. The results obtained by Lou, Yan, and Zhang (2013) and Beetsma, Giuliodori, de Jong, and Hanson (2016) for sovereign bonds are also consistent with the theory of primary dealers' limited risk-bearing capacity. 
makers and academics ${ }^{4}$, or to obtain market-implied default risk estimates in advanced internal rating-based (IRB) approaches. Our results would also have implications for diversification purposes, given the distortion in CDS correlations that arises from this trading. A more transparent market would improve the informational efficiency of prices and comovements by lessening the impact of large dealers trading pressures.

4. See, for instance, Gonzalez-Páramo (2011), Constancio (2012), or Hart and Zingales (2012). 


\subsection{Data and Sample}

Intraday CDS quotes disaggregated at the dealer level come from a dataset provided by Credit Market Analysis (CMA hereafter) for 11 EMU countries (Austria, Belgium, Finland, France, Germany, Greece, Ireland, Italy, Netherlands, Portugal, and Spain), spanning from January 2008 to October 2011. The same information is employed for an additional sample of 39 nonEMU countries from January 2010 to October 2011. We primarily focus on the EMU countries for three reasons. First, the level of contagion among these countries during the crisis has been very strong and has persisted for a long period of time. Second, the activity in the EMU sovereign CDS contracts has increased significantly. ${ }^{5}$ Third, all of the CDS have similar characteristics in terms of currency, restructuring clauses, and timing. Although most of the action occurs in the European sovereign CDS, we extend our analysis to the whole universe of sovereign CDS contracts to confirm the robustness of our results, showing that the findings are not influenced by the strong credit risk contagion among European countries.

CMA collects its intraday CDS quotes (both executable and indicative) from a robust consortium which consists of around 40 members from the buy-side community (hedge funds, asset managers, and investment banks) who are active participants in the CDS market. ${ }^{6,7}$ The quotes collected by CMA are provided by the sell-side (hereafter dealers) to the buy-side investors. As explained in Qu and Yu (2012), the process of trading in the CDS market usually begins with clients receiving indicative quotes from dealers through information providers such as Bloomberg. They then initiate a request-for-quote with a single dealer or multiple dealers by phone, email, or through an electronic trading platform. Dealers can respond with competitive binding quotes, which often result in actual transactions. They can also respond with noncompetitive quotes with wide bid-ask spreads or choose not to provide quotes if they do not wish to trade. Each single quote in our sample corresponds to a single dealer whose identity is not observed, but is indicated through a randomized number that is maintained constant for each dealer over the sample period. Every quote offers information on the bid and ask prices and the time in which it is recorded. In fact, the daily data reported by CMA come from these intraday quotes that are aggregated to a daily frequency. Contrary to other CDS data venders, Credit Market Analysis (CMA) DataVision does not categorize its CDS prices along the "composite" or "consensus" lines but uses a strict aggregation methodology to offer daily prices depending on the intraday market activity. The data aggregation is not equally weighted but the different weights are based on the respective age and length of the original sample employed (the last contribution is more influential than the older ones).

5. According to data provided by DTCC, France, Italy, Germany, and Spain were among the top 5 reference entities in terms of the net notional amount outstanding by September 2011, including sovereign and corporate references. Belgium, Austria and Portugal were in 11th, 12th, and 14th place, respectively. Compared to the remaining sovereign CDS, the net amount outstanding for the $11 \mathrm{EMU}$ countries in our sample ( $\$ 108$ billion) was 1.33 larger than for the rest of the sovereign CDS ( $\$ 81$ billion) by January 2010.

6. The term buy-side should be viewed from the perspective of securities exchange services that the buy-side uses to trade securities; whereas the sell-side, also called prime brokers, are the sellers of those services. Thus, the buy-side investors in the CDS market can be either protection buyers or sellers.

7. The buy-side community includes major credit-focused houses that receive up to 20,000 e-mail pricing messages a day, covering a wide array of credits; and boutique experts focusing on niche credits. These contributors are spread geographically across Europe and the US. Each of these members contributes their CDS prices to a CMA database which they receive in Bloomberg formatted messages (as well as forms) from their sell-side dealers. Hence, CMA has access to a constant stream and continuously evolving pool of CDS data. The access to OTC communication between buy-side trading desks and their counterparties guarantees that the prices received by CMA from the buy-side community are very likely to be tradable or even executable prices, and that they capture market conditions as they evolve throughout the day. Of course, it is difficult to know precisely whether all of them are tradable or not (Mayordomo, Peña and Schwartz, 2014). 
The CDS quotes employed in this study are 5-year maturity contracts (the most liquid ones) denominated in US Dollars. For those observations for which we only have information on the CDS up-front prices and not for the CDS spreads, ${ }^{8}$ we calculate the spread following the ISDA CDS Standard Model to convert up-front payments into spreads. ${ }^{9}$ To guarantee a minimum level of synchronicity across EMU countries, we exclude quotes outside the main working hours (7am to $8 \mathrm{pm} \mathrm{GMT+1)}$ and quotes given on Saturdays and Sundays. ${ }^{10}$ Information related to control variables comes from other sources and will be further explained in subsequent subsections.

Table I reports the summary statistics of the final sample of CDS quotes and the share of quotes by dealers. Panel A disaggregates the total number of quotes and dealers for the EMU countries, as well as the daily average, at the country level. Each country has an average of approximately half a million quotes and more than 650 daily quotes on average. There is an average of 28 different dealers giving quotes for each country on a daily basis. Each country has approximately 90 different dealers. Panel B contains the aggregate descriptive statistics for the EMU and non-EMU countries. For comparability reasons (due to data availability for the non-EMU countries) the sample spans from January 2010 to October 2011. In this sample of countries we use all available quotes, independently of the reporting time due to the different time zones. This panel confirms that the activity in the $11 \mathrm{EMU}$ countries is higher than the observed in the remaining 39 non-EMU countries, both in terms of the total and the daily average number of quotes. These figures reinforce the importance of understanding the effect of dealers' common quotes on the comovements of most liquid CDS. In fact, for this sub-period, the average number of daily quotes for each individual EMU country is around 838, versus 229 for each individual non-EMU country. The total and the average number of dealers reporting prices on a daily basis for the two groups of countries are very similar.

Panel $\mathrm{C}$ shows that the 10 most active dealers provide $45.9 \%$ of the total number of quotes in our sample, and the 30 most active dealers account for $90.8 \%$ of the total quotes. This feature emphasizes the high concentration in dealership in the CDS market.

A summary of the dynamics of the monthly correlation of daily sovereign CDS returns for countries $i$ and $j$ in month $t\left(\rho_{i j t}\right)$ for the sample of 11 EMU countries (55 different countrypairs) for the period of January 2008 to October 2011 is shown in Panel A of Figure 1. CDS returns refer to the percentage change in the daily CDS spread, and it is obtained as the first difference in the logarithm of the CDS spreads. ${ }^{11}$ The daily CDS spreads come from Markit instead of CMA to avoid any dependence on the method used by CMA to compute daily prices from the intraday contributions of dealers. ${ }^{12}$ The figure shows the median of $\rho_{i j t}$, jointly with the $5^{\text {th }}$ and $95^{\text {th }}$ percentiles. From the beginning of the sample to the collapse of Lehman Brothers, we observe a wide dispersion across correlations ranging from -0.56 to 0.93 . Since September 2008, the median of the correlations has fluctuated steadily between 0.43 and 0.86 . The $5^{\text {th }}$

8. Some dealers only provide up-front prices for Greece after April 2011.

9. http://www.cdsmodel.com/

10. Quotes outside these hours and on weekends are scarce; in fact, they represent $2.25 \%$ of all observations. Due to the low percentage of excluded quotes, we find similar results when we include them in our analysis.

11. We use the percent change in CDS spreads as in Hilscher, Pollet, and Wilson (2015). However, as these authors state, this implicit return is economically different from the excess return on a corporate bond implied by the identical CDS spreads, as considered by Berndt and Obreja (2010). For a detailed description of the logic of computing CDS returns as percent changes in CDS spreads see Hilscher, Pollet and Wilson (2015).

12. As detailed in Mayordomo, Peña, and Schwartz (2014), the Markit Group collects CDS quotes contributed by more than 30 major market participants on a daily basis. The quotes are subject to filtering that removes outliers and stale observations. Markit then computes a daily composite spread only if it has two or more contributors. 
and $95^{\text {th }}$ bands show a small dispersion in March 2009 consistent with the implementation of the economic stimulus package in the US. On the contrary, we observe a greater dispersion since May 2010 when there is a sizeable decrease in correlations in the $5^{\text {th }}$ percentile. This comes as a consequence of the disproportionately large increase of the Greek and other peripheral CDS premia in comparison to the core countries' CDS premia.

Our regression analysis relies on the correlations among sovereign abnormal or filtered CDS returns (instead of CDS returns), which we labeled "CDS excess correlation". These correlations can be interpreted as a contagion according to Bekaert, Harvey, and $\mathrm{Ng}$ (2005), who define contagion as "excess correlation, that is, correlation over and above what one would expect from economic fundamentals." Like Bekaert, Harvey, and Ng (2005), we take an asset pricing perspective on measuring economic fundamentals and identify contagion through the correlation of an asset pricing model's residuals. These residuals are obtained from a monthly regression in which the dependent variable is the daily CDS return of a given country obtained from Markit and the explanatory variables are three factors related to the CDS, bond, and stock markets. In the part of the analysis that involves only EMU countries, we estimate the filtered daily CDS returns for a given country i by regressing its CDS returns on the following factors: (i) country i's stock market index returns, (ii) the returns on the country's benchmark 5-year sovereign bond, and (iii) a sovereign CDS industry-specific index that is constructed from European countries by Thomson Financial based on the Thomson Reuters composite CDS data. ${ }^{13}$ The average R-squared of the monthly regressions for the each individual country is 0.57 . In the part of the analysis that involves the entire universe of sovereign CDS, we use the same three factors, except that for the CDS market factor we use an equally-weighted average daily CDS returns of all countries in the sample excluding the country under analysis (because there is no constructed index available for the rest of the countries as a group).

We denote the monthly correlation of daily sovereign filtered CDS returns for countries $i$ and $j$ in month $t$ as $\rho_{i j t}^{*}$. Panel B of Figure 1 shows the median of $\rho_{i j t}^{*}$, jointly with the $5^{\text {th }}$ and $95^{\text {th }}$ percentiles. This variable fluctuates between 0.1 and 0.8 and exhibits a higher variation than the series in Panel A of Figure 1. The average CDS excess correlation across the EMU countries over the sample period (0.36) is much lower than the CDS correlation (0.64). The CDS excess correlation reaches its highest levels in September 2008 and April 2010 coinciding with Lehman Brothers' collapse and the month before the Greek bailout.

Table II reports the descriptive statistics of the monthly correlation of daily sovereign CDS returns and filtered returns and the monthly commonalities in quotes for countries $i$ and $j$. The inclusion of Greece increases the average level of the CDS premium due to the high level of credit risk in the Greek CDS after 2010. Nevertheless, the inclusion/exclusion of Greece from the sample does not lead to strong differences in the level of the commonalities in quotes or the CDS excess correlations. These commonalities, as well as the correlation between CDS filtered returns, exhibit an upward trend from the levels observed in 2008 that remain high from 2009 onwards. Nevertheless, the CDS excess correlations exhibit a weaker upward trend.

13. This equally-weighted index is available via Thomson DataStream (DS Mnemonic: DSESV5E) and reflects an average mid-spread calculation of the index's constituents. The only traded index on European sovereign CDS (SovX Western Europe) began trading on September 28, 2009. This index consists of 15 countries, but its start date is far away from the beginning of our sample. 


\subsection{Measuring Commonality in Quotes}

\subsubsection{COMMONALITY IN QUOTES}

Two countries will be more connected if they have many dealers in common and if those dealers are similarly active in giving quotes to those countries. We average across dealers the correlation of the number of quotes given by each dealer $d$ to both countries $i$ and $j$ in month $t$. We label this variable Commonality in Quotes (CQ), and define it as:

$$
C Q_{i j t}=\sum_{d=1}^{D_{t}} \omega_{d t} \operatorname{corr}\left(N Q_{i d t}, N Q_{j d t}\right) \in[-1,1]
$$

where $N Q_{i d t}$ and $N Q_{j d t}$ are the number of daily quotes given to country $i$ and country $j$, respectively, by dealer $d$ in a given month $t$, and $D_{t}$ is the total number of dealers reporting quotes to both countries $i$ and $j$ in month $t$. If dealer $d$ does not report quotes for a country on a certain day, we impute a zero value for that day. The correlation of quotes coming from a very active dealer should weigh more than the correlation coming from a dealer that gives very few quotes. As a consequence, the Commonality in Quotes is a weighted average of the monthly correlation between the number of daily quotes reported by all dealers to countries $i$ and $j$ in which the weight assigned to dealer $d$ in month $t\left(\omega_{d t}\right)$ is defined as follows:

$$
\omega_{d t}=\frac{\min \left(T Q_{i d t}, T Q_{j d t}\right)}{\sum_{d=1}^{D} \min \left(T Q_{i d t}, T Q_{j d t}\right)}
$$

where $T Q_{i d t}$ and $T Q_{j d t}$ are the total number of quotes given by dealer $d$ to countries $i$ and $j$ at month $t$, respectively, such that the numerator of equation (2) measures the importance of dealer $d$ giving common quotes to countries $i$ and $j$. If a dealer gives 1 quote to France and 10 quotes to Spain, we say that France and Spain only share "1 common quote" from that dealer, the minimum of the two. The denominator is the sum of the numerator to ensure that the sum of $\omega_{d t}$ across all dealers in each month is equal to one.

This measure, Commonality in Quotes, captures how connected two countries are, depending on the activity, size, and number of dealers handling CDS for those two countries. We hypothesize that if there is a very active dealer giving many quotes to two countries in a pair, the CDS of those countries will exhibit a high level of comovement.

Figure 2 shows the median of the variable Commonality in Quotes obtained from equation (1), together with its $5^{\text {th }}$ and $95^{\text {th }}$ percentile bands. We observe that from the beginning of the sample to May 2009, the median displays an upward trend increasing from 0.48 to 0.91 while the $5^{\text {th }}$ and $95^{\text {th }}$ percentiles tighten, reaching the tightest point in May 2009. There is a clear and significant time-series variation in this variable and a relatively high dispersion across the different countries in the sample, in view of the 5th and 95th percentiles.

\subsubsection{COMMONALITY IN QUOTES AND DEALER'S TRADING PRESSURE}

We now turn to a more disaggregated version of the Commonality in Quotes. Consistent with seminal papers on market microstructure (see for instance Ho and Stoll, 1983), we consider that a dealer who is willing to reduce her position in CDS will decrease both the bid and ask prices. On the contrary, a dealer who is willing to buy CDS (and not sell) gives a high bid and ask price to ensure the purchase and deter additional buyers. This willingness towards a joint sale or joint buy of the CDS of a given pair of countries could lead to greater comovement. If 
that dealer is active enough, the CDS spreads quoted for the two countries would change simultaneously due to the dealer's activity, but not because of the two countries' similarities in fundamentals.

To capture the effect of trading based on buying or selling pressure, we break down the variable Commonality in Quotes in three variables. Commonality in Quotes from Buying Pressure $\left(C Q_{i j t}^{B}\right)$ is defined as in equation (1), but using quotes from those dealers facing buying pressure. These dealers are willing to buy CDS but less willing to sell protection and so, they are supposed to give high bid and ask quotes relative to other dealers. We consider that a dealer $d$ faces buying pressure on countries $i$ and $j$ when her average bid price and ask price in month $t$ are above the $66^{\text {th }}$ percentile of the distribution of all dealers' bid and ask prices for both countries. In the same vein, Commonality in Quotes from Selling Pressure $\left(C Q_{i j t}^{S}\right)$ is defined using quotes from those dealers facing selling pressure on countries $i$ and $j$. It occurs when her average bid price and ask price are below the $33^{\text {rd }}$ percentile of those distributions. ${ }^{14}$ Finally, we obtain Commonality not from Buying or Selling Pressure $\left(C Q^{N B S}\right)$ computed with those dealers that are not in the $B$ or $S$ category.

$$
C Q_{i j t}^{l}=\sum_{d=1}^{D_{t}^{l}} \omega_{d t}^{l} \operatorname{corr}\left(N Q_{i d t}^{l}, N Q_{j d t}^{l}\right) \in[-1,1] \text { where } l=B, S, N B S
$$

where I denotes whether dealer $d$ reporting CDS quotes to countries $i$ and $j$ faces buying pressure $(B)$ or selling pressure $(S)$ or none $(N B S)$ in both countries $i$ and $j$. Thus, we have a commonality variable for each of the three previous possibilities. The notation is similar to the one employed in the baseline commonality variable, but now $N Q_{i d t}^{l}$ and $N Q_{j d t}^{l}$ are the number of quotes given to country $i$ and country $j$, respectively, by dealer $d$ with a level of trading pressure / in a given month $t$. Regarding the weights $\left(\omega_{d t}^{l}\right)$, they are obtained as in equation (2) but considering separately the dealers in the category of trading pressure / to countries $i$ and $j$ at time $t$, respectively. $D_{t}^{l}$ denotes the total number of dealers in each of the three categories, denoting the degree of trading pressure / reporting quotes to both countries $i$ and $j$ in month $t$.

\subsection{Modeling Sovereign CDS Comovement}

The following equation represents the panel estimate regression explaining the monthly correlation of daily sovereign CDS excess returns for countries $i$ and $j$ in month $t\left(\rho_{i j t}^{*}\right)$ for the sample of 11 EMU countries (55 different country-pairs) for the period from January 2008 to October 2011:

$$
\rho_{i j t}^{*}=a+b * C Q_{i j t}+\sum_{k=1}^{K} b_{k} * \operatorname{CONTROL}_{k i j t}+\varepsilon_{i j, t}
$$

where $C Q_{i j t}$ refers to our measure of Commonality in Quotes that dealers give to both countries in the pair at month $\mathrm{t}$ obtained from equation (1) as defined in Section II.B. CONTROL $_{k i j t}$ contains the set of $k$ controls that include a group of pair-level variables and global risk factors. All of these controls are explained in the following subsection and are defined as contemporaneous to the dependent variable. We apply the Fisher's ztransformation to all variables that are correlation coefficients. ${ }^{15}$ Thus, both the dependent variable and the variable of interest $(C Q)$, among other controls, are transformed with this

14. We use these percentiles to guarantee a minimum number of observations to compute the correlations. We require that the dealers provide quotes for at least two days to consider their quotes in the computation of the commonality measure.

15.. The equation used for the Fisher's z-transformation of each correlation coefficient $(r)$ is as follows: $\left(0.5^{\star}[\ln (1+r)-\ln (1-r)]\right)$. 
method. The standard errors are double-clustered at the country-pair and month levels. In two different specifications we use the two versions of $C Q$ : the baseline one and the disaggregated one in trading pressure faced by dealers.

\subsection{Controls}

This set of variables accounts for differences and similarities between two countries that may potentially affect the comovements in the CDS spreads. We control for three groups of country-pair specific variables: credit risk of financial institutions, CDS liquidity, and macroeconomic variables. For every pair of countries, we measure the monthly correlation of each of the above variables, computed using daily observations. Given the lower frequency of the macroeconomic variables however, we use the absolute value of their difference to proxy for the similarities in terms of macro fundamentals.

Credit risk of financial institutions: Acharya, Drechsler, and Schnabl (2014) document a significant comovement between bank CDS and sovereign CDS after the announcement of financial sector bailouts in the Eurozone. As a consequence, the stronger the relationship between the financial sectors of two given countries, the more easily the shocks to financial institutions in the first country affect the sovereign sector of the second country. To control for this comovement, we consider the correlation between the log return of the CDS spreads of the banking sectors of the corresponding countries (Corr. Country Banks CDS Log Ret.).

CDS liquidity: Previous literature has documented the existence of a liquidity premium in sovereign CDS prices; thus, the higher the correlation between the liquidity premium of two countries, the larger the correlation in CDS prices would be. To proxy for the effect of liquidity in the comovements, we use the correlation between the sovereign CDS liquidity (Corr. CDS Relative Bid-Ask), proxied by the relative bid-ask spread (i.e., bid-ask spread relative to the mid-spread).

Macro variables: We consider two macro fundamentals in our analysis: government debt and the government net deficit/surplus relative to GDP. Using these variables, we proxy for the stock of debt in countries and the accumulated deficit. They have been found to have significant effects on the sovereign CDS spreads in Aizenman, Hutchison, and Jinjarak (2013) and Beirne and Fratzscher (2013), among others. We use the absolute differences in relative debt (Abs|Debt to $G D P_{i}$ - Debt to $\left.G D P_{j} \mid\right)$ and deficits (Abs|Deficit to $G D P_{i}$ - Deficit to $\left.G D P_{j} \mid\right)$ to measure the similarities across countries in terms of these two variables.

Longstaff, Pan, Pedersen, and Singleton (2011) study the nature of sovereign credit risk based on CDS spreads, and show that the majority of sovereign credit risk can be linked to global factors (a single principal component accounts for $64 \%$ of the variation in sovereign credit spreads). In view of this, it is highly plausible that all correlations are driven by a common set of factors besides the pair specific similarities or differences. For this reason, we include global risk factors in the regression model to rule out common aggregate factors that move all correlations up or down together. Specifically, we use the percentage change of the following global risk factors: ${ }^{16}$

16. Given that the regression is performed on a monthly basis, we first compute the monthly average of each variable and then we obtain the percentage change with respect to the previous month. We use the percentage change to be consistent with the definition of the rest of the variables. In addition we repeat the same exercise using the global factors in levels and obtained similar results. 
Systemic risk: We measure systemic risk by means of the 3-month Euribor-OIS spread ( $\triangle$ Log Euribor-OIS), that was found to be one of the most reliable measures of this risk in Rodriguez-Moreno and Peña (2013). Bhansali, Gingrich, and Longstaff (2008) document in the context of the subprime crisis and based on credit derivatives markets that systemic credit risk has become a much larger fraction of total credit risk. For this reason, we expect that exacerbations in the level of systemic risk are accompanied by increases in CDS comovements.

Sovereign and corporate credit risk: Bond yields and spreads represent an alternative measure of credit risk to CDS spreads. We use a synthetic Euro benchmark bond to measure the sovereign risk in the euro area ( $\triangle \log E A$ Treasury Yield). Moreover, we use the investment grade spread, which is obtained as the difference between the BBB- and AAA-rated euro corporate bond yield indices, to proxy for corporate credit risk. We expect stronger comovements during periods of higher financial stress.

Counterparty risk: The higher the counterparty risk, the lower the confidence among institutional investors in the CDS market, and thus, the more difficult it is to find a counterparty to buy or sell protection, the lower the market activity and the higher the correlation risk. As in Arora, Gandhi, and Longstaff (2012), we use the dealers' CDS spreads to construct the counterparty risk variable. We follow Arce, Mayordomo, and Peña's (2013) methodology, and proxy counterparty risk in the CDS market through the first principal component obtained from the CDS spreads of the main 14 banks that act as dealers in that market ( $\Delta$ Log Counterparty).

Risk premium: The risk premium has been found to have a positive effect on credit risk in existing literature (Dieckmann and Plank, 2012). We measure this risk premium by means of the Euro Stoxx 50 index ( $\triangle$ Log EUROSTOXX50). 


\subsection{Determinants of Comovements}

\subsubsection{BASELINE ANALYSIS}

Table III reports our baseline results. We employ two alternative specifications for which we report the results without (column (1)) and with (column (2)) the Commonality in Quotes variable to emphasize its power in explaining comovements. Both columns (1) and (2) contain all the control variables plus time effects. Regarding the new variable included in column (2), we observe a positive and significant effect of the Commonality in Quotes variable: increases in the common quotes significantly increase the correlation between the sovereign CDS excess returns. Concretely, an increase of $1 \%$ in Commonality in Quotes increases the correlation between their CDS excess returns by $0.14 \%$, ceteris paribus. Apart from being statistically significant, the explanatory power of this variable seems to be sizeable, because the R-squared increases $23 \%$ : from $8.6 \%$ to $10.6 \%$ after its inclusion in the regression.

Regarding the control variables, we observe that, consistent with the existence of a significant liquidity premium in CDS spreads, the stronger the relationship between the liquidity of the CDS contracts for a given pair of countries, the stronger the comovements in their prices. The similarities in the degree of the countries' deficits and indebtedness play a significant role in comovements: if two given countries exhibit a high ratio of deficit relative to GDP or debt to GDP, the market tends to push their CDS in the same direction. The only global variable that exhibits a weakly significant effect on the dependent variable is the EuriborOIS spread. This supports the evidence documented by Bhansali, Gingrich, and Longstaff (2008) according to whom systemic credit risk has become a much larger fraction of total credit risk. It is not surprising that the rest of the global variables are insignificant in the specification, given that we filter CDS returns with a three factor model that includes stock, bond, and CDS indices, which already incorporate the variability in global fundamentals, that should captured by the global variables used in this regression analysis.

We next analyze the economic significance of the variables according to the baseline results obtained in column (2). It is obtained from the product of the estimated coefficient and the standard deviation of each independent variable. The results are reported in column (3). The coefficient with the largest economic significance is the one of Commonality in Quotes. A change equal to one standard deviation of the previous variable would lead to an increase in the average excess correlation between the CDS of a given pair of countries equal to 0.052 units. This increase is equivalent to $17.4 \%$ of the dependent variable across the sample period (0.299). In view of these results, we conclude that our simple measure of commonality in the quotes that dealers provide for CDS of EMU countries is a powerful driver of the variation in CDS excess correlations.

The revision of the misleading statistics of fiscal deficits by the Greek authorities in November 2009 was the immediate trigger of the European sovereign debt crisis. We analyze the potential effect of the most influential event in the sample by excluding Greece from our baseline analysis, in Table IV, column (1), and splitting the sample into two sub-periods using this event as the break point: pre-crisis (column (2)), and crisis (column (3)). Independently of the exclusion of Greece and the sample period employed in our analysis, we find that the Commonality in Quotes has a positive and significant effect on the CDS excess comovement. 


\subsubsection{ROBUSTNESS TESTS AND EXTENSIONS}

This section contains a number of robustness tests. The first test concerns the use of alternative frequencies and alternative sample of countries in the regression analysis. The second test deals with the potential bias generated by the lack of trading in a given contract, whereas the third one poses an alternative methodology based on the dealers' characteristics and trading behavior. An additional battery of robustness tests is reported in the Internet Appendix.

a. Alternative Frequencies and Alternative Sample of Countries

We next show that the effect of the commonality does not depend on the data frequency employed. To that end, we use an alternative time frame in our analysis to build on the results obtained with monthly frequency. Thus, we perform a regression analysis in which the variables are defined at weekly frequency. For instance, the Commonality in Quotes is obtained as in equation (1) but by computing weekly correlations from the number of quotes per day. The same procedure is applied to the rest of correlation variables and for the global variables we take the weekly average. ${ }^{17}$ Regarding the remaining independent variables, the absolute differences for a given pair of countries in the ratios of debt and deficit to GDP are those used in Table III and have a quarterly frequency. As shown in column (1) of Table V, independently on whether we perform the regressions on a monthly or weekly basis, the variable of interest still plays a significant role on the CDS comovements.

To analyze whether the results in our paper are short-lived or not, we test whether the commonalities in quotes are powerful predictors of CDS comovements one week ahead. For that aim, we estimate a variation of equation (4) in which all explanatory variables are lagged one week. The results are reported in column (2) of Table V. We observe that the coefficient associated to the Commonality in Quotes is not statistically different from zero suggesting that this effect is contemporaneous or short-lived. This result is consistent with the signature prediction of asset markets with frictions, stating that frictions tend to disappear and align more closely with fundamentals.

Finally, to ensure that the results are not due to the strong similarities among the 11 EMU countries forming the sample, we next extend our analysis to the entire universe of sovereign CDS for which there are regular quotes. This leads to a final sample that consists of 50 countries (39 non-EMU countries) for the sample period 2010-2011. Column (4) of Table V contains the results obtained for the baseline specification extended to all countries. ${ }^{18}$ We still find a positive and strongly significant effect of commonalities.

b. Dealing with the lack of trading

The dealer commonality measure could be biased towards the excess commonality by counting in non-tradable quotes. This upward bias could affect ultimately the effect of the commonality in quotes on the CDS comovements. For this reason we perform several robustness tests, to deal with the potential biases caused by non-traded contracts.

We first remove from the sample the most inactively traded countries. We cannot differentiate the tradable and non-tradable quotes in our dataset. However, we exploit the information in DTCC that contains the number of contracts traded in a given week. We

17. Instead of using weekly averages in a given week we use the last observation available one week before and obtain similar results.

18. Due to the lack of information on the banking sector CDS spreads of many non-EMU countries, we substitute the credit risk of the financial institution control variable by the absolute difference of bank nonperforming loans to total gross loans defined on an annual basis (Abs|NPLTLi - NPLTLj|). 
consider as actively traded contracts those ones traded every week in a given month and as inactively traded contracts those in which there is not trading in at least one week of the month. The results reported in column (1) of Table VI correspond to the sample formed by European countries, and are obtained using all the contracts and months for which there is information in DTCC (i.e., November 2008 - October 2011). The results contained in column (2) refer to the case in which we remove the inactively traded contracts. Concretely, the sample consists of pairs of countries in which both countries are actively traded. The coefficient in column (2) is similar to the one in column (1) in which the whole sample of European countries is used for the analysis. In fact, the difference between the two coefficients is not statistically different from zero. In addition, the economic impact of commonalities on the comovement, which is obtained as the product of the coefficient and the standard deviation of the corresponding measure of commonality, exhibit a relatively similar magnitude, suggesting that there is not an overestimation of the effect of commonalities due to the presence of non-actively traded contracts. The fact that the two coefficients exhibit the same order of magnitude could be due to the similar number of observations used in the two regressions given that the European sovereign CDS contracts are very actively traded. For this reason, we extend the sample to the whole universe of sovereign CDS and perform a similar analysis. We observe that the coefficient obtained for both traded and non-traded contracts (column 3 ) is in fact lower than the one obtained for countries that are traded (column 4). The difference between both coefficients is statistically different from zero and the economic impact of the measure of commonalities in quotes is higher under the specification used in column (4) discarding an upward bias caused by non-traded contracts.

As a second attempt to deal with this issue, we perform two similar analyses that are implemented based on pairs formed by non-actively traded countries and pairs formed by an actively traded country and another one that is not. To perform these analyses with a reasonable number of observations in each regression, we propose a new classification to define actively and non-actively traded countries. For each month we compute the $33^{\text {th }}$ and $66^{\text {th }}$ percentiles from the distribution of the number of contracts traded on the sample of countries. Then, we define a contract for a given country as non-actively traded if the number of traded contracts on that country in that month is below the percentile 33th, whereas actively traded contracts are those that are above the $66^{\text {th }}$ percentile. ${ }^{19}$ The results obtained when the sample consists of pairs formed by non-actively traded contracts according to the new definition are reported in column (5) whereas the ones obtained for pairs in which a contract is actively traded and the other is not are reported in column (6). A formal test to compare the magnitude of the coefficients reveals that the coefficient in column (5) is not statistically different from the one obtained under the baseline specification for the whole universe of countries (i.e., column (3)) whereas the one in column (6) is significantly lower than the baseline coefficient. Similar conclusions are inferred if we attend to the economic impact of the commonalities in quotes on the dependent variable.

c. Dealers characteristics and trading behavior

In this subsection we conduct a complementary analysis that provides additional evidence on the return comovements due to common dealers. We consider that a given pair of CDS has a common dealer if the specialist in both countries is the same. To define a dealer as a specialist in a given CDS contract, we consider a variation of the term specialist in Coughenour and Saad (2004). Their analysis relies on the NYSE specialist system according to which specialists are those traders that specialize in a particular stock by maintaining a fixed position at a post on the NYSE floor and execute orders for other brokers.

19. We have used other percentile 25th / 75th, and the median to split the contracts as actively and non-actively traded, and both obtain similar results. 
Our data corresponds to an OTC market for which there is not a formal definition of specialist, and thus we propose a method to classify market makers as specialists depending on their quoting activity. To that aim, we use the whole universe of sovereign CDS. It guarantees the existence of a higher number of CDS contracts that are traded by different dealers, such that each country or group of countries has different specialists. Although our dataset consists of quotes, we get information from DTCC on the number of contracts traded in a given week. This information enables us to assign the best bid and ask quotes to potential purchases and sales of CDS. As a first attempt, to construct the inventory for each dealer we order the bid and ask prices obtained from the dealers in a type of limit order book, in which we assume that the highest (lowest) bid (ask) prices within a given week are the most likely ones to end up in trades. This strategy enables us to "infer" the number of contracts traded by each dealer each week and to aggregate them at the monthly level, which allows us to classify them as specialists in a given country. We consider three alternative methods to classify specialist dealers:

a) A dealer whose average number of monthly trades, independently on whether they are purchases or sales, is the highest across all dealers.

b) A dealer with the highest number of accumulated trades independently on whether they are purchases or sales.

c) A dealer that has been the most active trader in the highest number of weeks.

One could argue that the price variation within a given week could be so high that the creation of the limit order book on a weekly basis is not adequate. For that reason, we define the limit order book at a daily level, and assume that the best bid and ask prices in a given day are the ones that are more likely to be tradable. To that end, we divide the number of trades in a given week by the number of banking days in that week to determine the dealers that are taking either long or short positions that day. When the result of the division is not an entire number we distribute the remaining trades within the week days proportionally to the number of quotes in each day. Finally, we define three measures of specialists in agreement with the measures a) - c) detailed above.

Based on the definition a) obtained on a daily basis (i.e., average number of monthly trades), our sample consists of 5 specialists and so, on average, each specialist acts as such in more than 8 countries out of the 41 used in the regression analysis. The most frequent specialist is specialized in 17 countries (i.e., around $41.5 \%$ of the countries in the sample). This suggests that there exists certain heterogeneity that could help us to define a "dealer factor" following Coughenour and Saad's (2004) methodology. These authors rely on the liquidity market model used by Chordia et al. (2000) to provide evidence of positive time-series stock liquidity co-variation, and extend it by incorporating information about the specialist firm portfolio. It enables Coughenour and Saad (2004) to document the existence of stock liquidity comovement with the liquidity of other stocks handled by the same specialist firm.

Our analysis relies on CDS returns instead of liquidity, but we adapt Coughenour and Saad's (2004) model specification to our data to understand the existence of comovement in CDS returns with the returns of other CDSs handled by the same specialist. For that aim we extend a market model where the dependent variable is the CDS return, which is regressed on a market factor and a dealer factor:

$$
D C D S_{i t}=\alpha+\beta_{1} D M k t C D S_{i t}+\beta_{2} D S p C D S_{i t}+\varepsilon_{i t}
$$


where $D M k t C D S_{t}$ is the market factor for the CDS of country $i$, that is defined as the average CDS daily return across the remaining 40 countries. The dealer factor for country $i$ is defined as the average daily return across all the countries with the same specialist as country $i$, excluding this country. Thus, the variable $D S p C D S_{i t}$ denotes the country i's specialist portfolio returns that is obtained as the average daily return across all the countries that share the same specialist, excluding country $i$. The correlation between the market and dealer factors is around 0.75 , which suggests that the dealer factor is indeed distinguishable from the market factor, and consequently we do not have an identification problem. ${ }^{20}$

This regression is implemented for each definition of specialist, and the results are contained in Table VII. We report the average estimate for the two factors and the t-statistic associated to a test that analyses if the average estimate across all the countries is statistically different from zero. Results in columns (1) - (3) refer to the case in which the trades are assigned on a weekly basis whereas results in columns (4) - (6) correspond to the case in which the trades are assigned on a daily basis. The results show that in fact the coefficients associated to both the market and dealer factors are positive and statistically different from zero for all the specialist definitions, and confirm that the dealer commonality has a strong explanatory power beyond market factors. In sum, this analysis provides further evidence in favor of the existence of comovement in CDS prices derived from the dealers that actively give quotes to a given pair or group of countries.

\subsection{Comovements and Dealers' Trading Pressure}

In this section, we perform a test to analyze the effect of the commonalities obtained from dealers facing trading pressure. We disaggregate the Commonality in Quotes into three different variables: one coming from Buying Pressure, another from Selling Pressure, and the last one not from Buying or Selling Pressure. This test is especially important because it helps us disentangle the origin of the effect. If the mechanism is a fundamental one, through information, then there should be no difference between the strength of the effect of the three different disaggregated variables. If, however, we find stronger effect from buying or selling pressure variables than the non-buying or selling (as we do), then it is consistent with a friction that is non-fundamental. As detailed in Section II.B, we consider common high (low) ask and bid prices for a given pair of countries to define dealers facing buying (selling) pressure. The commonalities obtained from dealers facing buying (selling) pressure for a given pair of countries are denoted as $C Q_{i j t}^{B}\left(C Q_{i j t}^{S}\right)$ while the ones obtained from dealers who do not face trading pressure are denoted as $C Q_{i j t}^{N B S}$. The results obtained for the joint use of the three types of commonalities are reported in column (1) of Table VIII. We observe that the effect of commonalities obtained from dealers facing buying pressure is significantly different from zero, while that for dealers facing selling pressure and those who do not face either buying or selling pressure is not. ${ }^{21}$ The coefficients of the remaining control variables remain unchanged. It suggests that dealers willing to increase their positions in a given pair of EMU countries contribute to increasing the CDS prices of those countries and, consequently, their correlation. This supports Shachar's (2013) finding that the contemporaneous price impact of buying is much larger than the immediate price impact of selling. Moreover, the role of dealers buying

20. The correlation coefficient is not far away from the average correlation coefficient between the change in market portfolio spreads and specialist portfolio spreads obtained by Coughenour and Saad (2004), which is roughly 0.70. The adjusted R-squared in the multivariate regression is higher than the ones obtained for the regressions with a single factor (either the market or the dealer factors) which confirms that near-multicollinearity should not influence the precision of the coefficient estimates (see Greene, 1990, p. 280).

21. A given dealer $d$ is considered as facing buying (selling) pressure for countries $i$ and $j$ when her average bid and ask prices are above (below) the 66th (33rd) percentile in both countries. The use of the 25th and 75th percentiles delivers similar results but leads to a lower number of observations to implement the analysis. 
pressure on CDS prices and comovements is supported by the increase in the real demand of dealers in the sovereign CDS market that exhibit an increasing trend since mid-2009 (see Klingler and Lando, 2014). These results are also in agreement with those obtained by Garleanu, Pedersen, and Poteshman (2009) and Bongaerts, de Jong, and Driessen (2011), among others, on the contribution of demand pressure to derivatives pricing.

Our finding is consistent with dealers being less willing to sell protection and further increasing their exposure to counterparty risk and to the default of a given EMU country. The effect of demand pressure on CDS comovements could be explained by the use of sovereign CDS as credit risk mitigants to reduce portfolio credit risk and/or to lower regulatory capital requirements. Sovereign CDS are appropriate instruments to hedge direct exposures to sovereign debt or hedge other assets whose value is correlated with the creditworthiness of the sovereign as banking or utility sectors (see April 2013 World Economic Outlook, IMF). Additionally, when a bank acquires a CDS against a risky investment, the bank can hold less capital against such investment. The use of CDS to lower regulatory capital requirements and to free up capital on banks' balance sheet has been addressed by Yorulmazer (2013), Klingler and Lando (2014), Hasan and Wu (2016), Shan, Tang, and Yan (2016), and Augustin, Sokolovski, Subrahmanyam, and Tomio (2017). ${ }^{22,23}$

There are additional frictions and features of the sovereign CDS market that could help explain the role of common quotes from dealers facing buying pressure. According to market microstructure literature, common demand of a pair of sovereign CDS may be the result of managing inventory risk on single securities traded by a dealer facing that risk (Shachar, 2013; and Gehde-Trapp, Gündüz, and Nasev, 2015). ${ }^{24}$ The buying pressure could also obey to the dealers' willingness to express their opinion or information on the country creditworthiness using naked CDS positions (Duffie, 2010).

Most of the quotes are reported by a small number of dealers (see Section II. A) and so, the commonalities in quotes associated to these dealers could have a stronger effect on the excess correlations. In fact, Mengle (2010) documents that the 14 largest dealers worldwide hold roughly $90 \%$ of the CDS notional amount. To deal with this issue we define a more disaggregated version of the commonalities in quotes variables for dealers facing buying pressure. To capture the effect of dealers' market power, we break down the variable Commonality in Quotes from Buying Pressure $\left(C Q_{i j t}^{B}\right)$ in two variables according to the dealer's activity. We define active dealers facing buying pressure in a given month $t$ as those whose total number of quotes to a given pair of countries is above the median $\left(C Q_{i j t}^{B>p c t l 50}\right)$ of the distribution of the total number of quotes per pair and dealer. Given that dealers contributing a high number of quotes are expected to trade more, it seems reasonable to refer to the active dealers as large dealers. Column (2) of Table VIII contains the results obtained from the joint use of the four types of commonalities. We observe that the effect of the Commonality in Quotes is dominated by the activity of larger dealers among those facing buying pressure. This finding is in agreement with Gehde-Trapp, Gündüz, and Nasev (2015), whose findings are

22. As illustrated by Yorulmazer (2013), AIG claimed in its public financial statements that $72 \%$ of the notional amounts of CDS sold by AIG Financial Products as of December 2007 were used by European and other banks for capital relief.

23. The new regulatory requirements due to Basel III that aim to reduce counterparty credit risk in derivatives transactions have also contributed to increase dealers' demand pressure (see Klingler and Lando, 2014).

24. Inventory control and risk-sharing has attracted significant attention in the stock market as a motive behind interdealer trading (see Garman (1976), Stoll (1978), Amihud and Mendelson (1980), Ho and Stoll (1983), O'Hara and Oldfield (1986), among others). According to this literature, dealers accommodate buying and selling by outside investors and adjust their quoted prices to restore their inventories to some desired level, thereby causing price movements. 
consistent with the "notion that the lack of competition in CDS markets gives rise to dealer market power with significant price impact".

Finally, we try to shed more light on the role of buying pressure on CDS comovements by means of a new definition of the trading pressure variables. For that aim, we classify the quotes as trades using information on the number of trades in a single week based on the method described in Subsection A.2.3. In sum, we use information from DTCC on the number of trades per week, and then assign as trades the best bid and ask quotes in each week. Then, we aggregate the number of weekly trades for each dealer at the monthly level to classify the dealers depending on their trading pressure in each month. Thus, a dealer faces buying (selling) pressure when his/her net trading position in a given month is positive (negative), which indicates that he/she is in fact buying (selling) CDS in that month. Those dealers whose net trading position in that month is equal to zero do not suffer either buying or selling pressure. Finally, we break down the variable Commonality in Quotes in three variables using separately quotes from those dealers facing (i) buying pressure, (ii) selling pressure, or (iii) neither buying nor selling pressure. The results obtained from the new measures of trading pressure are reported in column (4) of Table VIII and support the significant role played by the dealers facing buying pressure on CDS excess correlations.

\subsection{Accounting for Endogeneity}

In our analysis, we have regressed monthly CDS excess comovements on dealers' quote commonalities. Nevertheless, endogeneity may be a concern here because it is plausible that innovations in CDS excess comovements may simultaneously affect the dealers' common quotes through some behavior observed in such correlations. To conclude that the Commonality in Quotes is indeed causing an increase in CDS excess comovements, we reestimate the regressions reported in equation (4) using two different methods: an instrumental variable approach, and an analysis using the commonalities in quotes filtered from the three lags of CDS return correlations. In addition to dealing with endogeneity, the instrumental variable approach also strengthens our hypothesis of this effect coming from a nonfundamental friction. Indeed, if it was a different channel (different from the use of CDS as capital relief purposes), then we would not necessarily see a correlation of our instrument with our Commonality in Quotes variable, as we will see in the next few paragraphs.

We first consider the use of instrumental variables. We require an instrumental variable that exclusively affects the participants in the CDS market, not the entire economy. The channel through which we explain the effect of Commonality in Quotes on CDS excess correlation is the demand pressure of sovereign CDS to mitigate credit risk exposures for capital relief purposes. In the context of the Basel II Accord, banks should satisfy a minimum capital requirement defined as the ratio between core equity (or Tier 1 capital) and risk weighted assets (RWA). In the RWA calculation under the Standardised Approach, claims on sovereign debt are risk weighted depending on the rating of the issuer country: 0\% (AAA to AA-), 20\% (A+ to $A-), 50 \%$ (BBB+ to BBB-), 100\% (BB+ to B- or unrated), $150 \%$ (below B-). ${ }^{25,26}$ In view of this, we use as an instrument for each pair of countries the average quarterly Tier 1 capital ratio of a subset of internationally active banking institutions.

25. http://www.bis.org/publ/qtrpdf/r_qt1312v.htm

26. IRB risk weights for sovereign assets are even higher. For instance, the illustrative example provided in the previous link to the treatment of sovereign risk in the Basel capital framework assigns a weight of $7.53 \%$ to a sovereign asset with a probability of default of $0.01 \%$, a loss given default of $45 \%$, and a maturity of 2.5 year. 
The banks employed to obtain the average quarterly Tier 1 for a given pair of countries are those for which the sovereign debt of these countries has positive risk weights. These banks are selected as follows. First, we require that banks' headquarters are not located in any of the two countries/economic areas forming the pair. ${ }^{27}$ Second, we require that the domestic banks of a given country exhibit a positive exposure to the official sector of both countries forming the pair. ${ }^{28}$ There is not available information on the direct exposure of each individual bank to the sovereign debt of a given country. Instead, we use the consolidated bank statistics provided by the Bank of International Settlements (BIS) that contain information on the aggregate exposure of domestic banks in each country to the official sector of the counterparty countries in the pair. Third, we exclude banks with subsidiaries in any of the two countries forming the pair. This requirement is imposed to avoid imputing positive weights to those banks that purchase debt through their subsidiaries located in a given country.

Our instrumental variable proxies a demand shock on the sovereign CDS to hedge the credit exposures of the largest and global active banks where improvements of the average Tier 1 capital ratio are related to an efficient use of sovereign CDS. The motivation for the use of this instrumental variable relies on Yorulmazer (2013), Hasan and Wu (2016), Shan, Tang, and Yan (2016), and Augustin, Sokolovski, Subrahmanyam, and Tomio (2017) evidence about the use of CDS by banks to reduce the capital requirements for existing exposures (see also ECB, 2009). ${ }^{29}$ Concretely, Shan, Tang, and Yan (2016) document that banks' risk-weighted assets shrink after using CDS given that its use enables banks to shift assets from higher risk-weight categories to the 0\%-risk category. Thus, they are able to hold less capital while complying with the requirements of regulatory capital ratios. Hasan and Wu (2016) test five hypotheses on whether banks use CDS to hedge corporate loans, provide credit enhancements, obtain regulatory capital relief, and exploit banking relationship and private information. They find strong evidence for the credit enhancement and regulatory capital relief hypotheses. Subrahmanyam, Tang, and Wang (2014) also uncover the true effect of CDS trading on rating downgrades and bankruptcies by means of an instrument based on lenders' Tier 1 capital ratio. In fact, they find that the instrument is a significant predictor of CDS trading even after controlling for all other variables.

Given that information on the Tier 1 capital ratio is released on a quarterly basis, we define the dependent and independent variables on a quarterly basis. These data are obtained from COMPUSTAT and from the individual banks quarterly and annual reports when information is not available in COMPUSTAT. We use a sample of 48 large banking institutions from 14 countries to define the instrument. These international banks are among the ones used by López-Espinosa, Moreno, Rubia, and Valderrama (2012) in their analysis of systemic risk. ${ }^{30}$

27. Basel II Accord recognizes the national discretion of lowering the risk weight applied to their banks' exposures denominated in domestic currency and, in fact, it is often in practice zero. For this reason, in the case of EMU countries, we do not consider banks belonging to any of the EMU countries.

28. The "official sector" comprises the general government sector, central bank sector and international organizations (including multilateral development banks).

29. The use of CDS by banks to improve the appearance of their capital ratios could also have adverse effects. For instance, it could lead to an incentive to invest in highly risky projects (Yorulmazer, 2013), and, as a consequence, to increase systemic risk.

30. The list of banks and countries is as follows: Australia (Westpac, Commonwealth Bank, and National Australian Bank), Austria (Erste Group), Belgium (KBC Group), Canada (Royal Bank of Canada, Canadian Imperial Bank, Bank of Montreal, Bank of Nova Scotia, and Toronto Dominion), France (BNP Paribas and Societé Generale), Germany (Commerzbank and Deutsche Bank), Great Britain (Barclays, Lloyds, RBS, HSBC, and Standard Chartered), Ireland (Allied Irish Banks), Italy (Unicredit, Intensa Sanpaolo, and Monte dei Paschi di Siena), Japan (Nomura and Daiwa Securities Bank), Spain (BBVA, Banco Popular, Banco Santander), Sweden (Svenska Handelsbanken, SEB, Nodea Bank, and Swedbank), Switzerland (Credit Suisse and UBS), and United States of America (Regions Financial, Goldman Sachs, State Street, BB\&T, PNC Financial Svcs Group, Bank of New York Mellon, Morgan Stanley, US Bancorp, Suntrust, Citigroup, Bank of America, JP Morgan, Wells Fargo, and Capital One). 
The instrumental variable regression is based on equation (4) in which the Commonality in Quotes from Buying Pressure $\left(C Q_{i j t}^{B}\right)$ is instrumented through the abovementioned instrument. The regression is performed on a subset of pairs of countries from the whole universe of sovereign CDS described in Section II.A and summarized in Panel B of Table I. The analysis is conducted on those non-OECD countries with a rating category equal or lower than $\mathrm{A}+$ at any quarter over the sample period. These are pairs of countries whose long-term bonds have a positive risk weight that could favor the demand of sovereign CDS to reduce the capital requirements. The sample consists of 15 countries. ${ }^{31}$ Due to the use of nonEMU countries, the analysis relies on quarterly observations for the period 2010-2011.

Column (1) of Table IX reports the results for the instrumental variable analysis conducted on those pairs of countries. The results of the first stage in which we regress $C Q_{i j t}^{B}$ on the instrument are reported at the end of Table IX in column (1). The coefficient for the instrument is positive and significant at any standard level of significance. It suggests that improvements in the average Tier 1 capital ratio are related to an active control of the RWA through the demand of sovereign CDS for those countries whose bonds have positive risk weights. Column (1) of Table IX also reports the results of the second stage regression in which we use the fitted Commonality in Quotes from the first stage to explain the variation of CDS excess comovements. As can be inferred from the positive and significant coefficient for the instrumented variable (INST. $C Q_{i j t}^{B}$ ), we conclude that the potential endogeneity of these commonalities does not bias our results. ${ }^{32}$ This piece of evidence confirms that our finding does indeed come from a causal relationship between Commonality in Quotes and CDS excess return comovement.

To verify the validity of our instrument, we perform the Kleibergen-Paap Rank LM statistic to check whether the equation is identified, that is, whether the excluded instrument (the average Tier 1 capital ratio for the corresponding subset of banks) is "relevant" (correlated with the endogenous regressor). According to this under-identification test, we reject the null hypothesis (equation is under-identified); thus, the instrument is relevant and the model is identified. ${ }^{33}$ As the previous instrumental regression is exactly identified, we consider the squared of the average Tier 1 capital ratio as an additional instrument to formally test the exogeneity of the instrument through the Hansen $\mathrm{J}$ statistic. Under the null hypothesis, all instruments are uncorrelated with the residual terms and thus, exclusion restriction is satisfied. According to the results available in column (2) of Table IX, we cannot reject the null hypothesis. As a consequence, we do not find evidence in favor of the violation of the exclusion restriction, and thus confirm the validity of the instrument.

It is not likely that the comovement in a given pair of CDS may affect significantly the average capital ratio of the sample of international banks used to define the instrument. These international banks are selected such that they do not have headquarters and subsidiaries in any of the two countries in the pair. In fact, the test for the exclusion seems to confirm that statement. However, to further confirm that our results are not affected by endogeneity, we perform a new instrumental approach in which use the average Tier 1 calculated for each pair of countries

31. The countries forming the sample are the following: Argentina, Brazil, Bulgaria, Colombia, Croatia, Egypt, Kazakhstan, Lithuania, Malaysia, Peru, Philippines, Russia, South Africa, Thailand, and Ukraine.

32. We perform a regression analysis to estimate the coefficients of equation (4) at monthly and quarterly frequencies based on the sample used to perform this IV analysis and find that the variable Commonalities in Quotes exhibits a positive and significant coefficient for both specifications.

33. We also perform a weak identification test to analyze whether the instrument is weakly correlated with the common quotes. In view of the Kleibergen-Paap Wald Rank F statistic, we reject the hypotheses that the equation is weakly identified. 
lagged one quarter. It is not reasonable that the comovements of CDS in a given quarter affect the aggregate bank capital ratio in the previous quarter because the dealers' quoting/trading activity takes place after the reporting of the capital ratio. The results obtained for the lagged instrument are reported in column (3) of Table IX and support the existence of a causal effect.

We perform an additional robustness check to rule out how banks' CDS quoting activity is correlated with CDS spreads. Thus, to show that the potential correlation between two CDS contracts and banks' balance sheet is not an issue, we filter even more our sample such that we restrict our IV analysis to a sample of countries with an average Fisher's transformed correlation that is between -0.35 and 0.35 such that it is not statistically different from zero. As shown in column (4) of Table IX, the instrumented variable exhibit a positive and significant coefficient consistent with the ones obtained in the two previous analysis of endogeneity, and supports the validity of our results.

Finally, we perform an additional analysis to ensure that our results do not suffer from endogeneity. According to Andrade, Chang, and Seasholes (2008), the cross-security price pressure that may lead to excess comovements across securities is higher among securities with more correlated fundamentals, for example, cash flows in the case of stocks. In addition to the instrumental variable analysis above, we now present an analysis that consists of two stages. In the first stage, we regress the Commonality in Quotes from Buying Pressure $\left(C Q_{i j t}^{B}\right)$ on three lags of the CDS return correlation and use the residuals as our variable of interest. Filtering the commonalities in this way ensures that the past effects of CDS correlations will not be an issue in our analysis. We implement it on the EMU countries employed in the baseline analysis, and the results are reported in column (5) of Table IX. These results strongly support the consistency of the results obtained in previous analyses. Although we have tried to defend the causal relation through several specifications and econometric strategies, it is important to acknowledge that they could present some shortcomings and limitations, given that there could be other alternative mechanisms in play behind the results that we cannot rule out. 


\section{Conclusion}

This paper analyzes the effect of the CDS market dealers' activity on the comovement of sovereign CDS spreads. The lack of information on intraday quotes at the dealer level leaves a gap in the literature documenting the role of dealers' activity in CDS contacts. The use of a dataset that consists of the intraday quotes contributed by each specific dealer enables us to fill this gap and provide new evidence about the role of non-fundamental factors in explaining such comovements in periods in which market frictions emerge in the CDS market.

We show that a simple measure of the connectedness of two sovereign CDS through their common dealers' quoting activity is a powerful driver of the variation in CDS excess return correlations. In fact, the economic impact of the commonality variable is much stronger than the impact attributable to other country-pair fundamentals such as credit, default, and liquidity risks and macro factors.

The strong effect of this Commonality in Quotes is explained by the strategy adopted by dealers to trade. If dealers face buying pressure in two countries at the same time, the joint purchases of CDS for those countries would lead to simultaneous changes in the prices of the two CDS. An instrumental variable analysis confirms that our findings indeed reflect a causal relationship between Commonality in Quotes and CDS excess comovement.

These results are consistent with the CDS premia containing a non-default-related component that strongly contributes to causing comovement across credit spreads. Thus, the economic magnitude of this non-fundamental based trading should be accounted for before extrapolating measures of contagion or comovement from CDS prices. This would improve the usefulness of CDS to monitor credit risk and contagion across countries. In addition, securities markets regulators should be aware of this finding, and make decisions accordingly to lessen the effect of non-fundamental price pressures on financial instruments traded in markets with few and large dealers.

Finally, the new evidence on the determinants of comovement among sovereign CDS spreads has important implications for the risk diversification of the euro zone debt portfolios; given that investors should understand that an important part of the comovement in their portfolios is not due to fundamentals but to commonalities in dealers' quotes. 


\section{REFERENCES}

ACHARYA V.V., DRECHSLER, I., and SCHNABL, P. (2014). "A Pyrrhic Victory? Bank Bailouts and Sovereign Credit Risk", Journal of Finance, 69, 2689-2739.

AUGUSTIN, P., SOKOLOVSKI, V., SUBRAHMANYAM, M. C., and TOMIO, D. (2017) "Why Do Investors Buy Sovereign Default Insurance?", Working Paper.

AïT-SAHALIA, Y., ANDRITZKY, J., JOBST, A., NOWAK, S., and TAMIRISA, N. (2012). "Market Response to Policy Initiatives during the Global Financial Crisis", Journal of International Economics 87, 162--177.

AIZENMAN, J., HUTCHISON, M., and JINJARAK, Y. (2013). "What is the risk of European sovereign debt defaults? Fiscal space, CDS spreads and market pricing of risk", Journal of International Money and Finance, 34, 37-59.

ALTER, A., and BEYER, A. (2014). "The Dynamics of Spillover Effects during the European Sovereign Debt Turnoil", Journal of Banking and Finance, 42, 134-153.

AMIHUD, Y., and H. MENDELSON (1980). "Dealership Market: Market-Making with Inventory", Journal of Financial Economics 8, $31-53$

ANDRADE, S. C., CHANG, C., and SEASHOLES, M. S. (2008). "Trading imbalances, predictable reversals, and cross stock price pressure", Journal of Financial Economics 88, 406-423.

ARCE, O., MAYORDOMO, S., and PEÑA, J. I. (2013). "Credit-risk valuation in the sovereign CDS and bond markets: evidence from the euro area crisis", Journal of International Money and Finance, 35, 124-145.

ARORA, N., GANDHI, P., and LONGSTAFF, F. (2012). "Counterparty Credit Risk and the Credit Default Swap Market", Journal of Financial Economics 103, 280-293.

BADAOUI S., CATHCART L., and EL-JAHEL L. (2013). "Do sovereign credit default swaps represent a clean measure of sovereign default risk? A factor model approach", Journal of Banking \& Finance, 37, 2392-2407.

BARBERIS, N., SHLEIFER, A. and WURGLER, J. (2005). "Comovement”, Journal of Financial Economics 75, $283-317$.

BEETSMA, R., GIULIODORI, M., DE JONG, F., and HANSON. J. (2016). "Domestic and cross-border auction cycle effects of sovereign bond issuance in the euro area", CEPR Discussion Paper No. 11122.

BEIRNE, J., and FRATZSCHER, M. (2013). "The pricing of sovereign risk and contagion during the European sovereign debt crisis", Journal of International Money and Finance, 34, 60-82.

BEKAERT G., HARVEY, C.R., and NG, A. (2005). "Market integration and contagion", Journal of Business, 78, 39-70.

BERNDT, A., and OBREJA, I. (2010). "Decomposing European CDS Returns", Review of Finance, 14, 189-233.

BHANSALI, V., GINGRICH, R., and LONGSTAFF, F. A., (2008). "Systemic Credit Risk: What is the Market Telling Us?", Financial Analysts Journal 64, 16-24.

BONGAERTS, D., DE JONG, F., and DRIESSEN, J. (2011). "Derivative Pricing with Liquidity Risk: Theory and Evidence from the Credit Default Swap Market", Journal of Finance 66, 203-240.

BROTO, C., and PÉREZ-QUIRÓS, G. (2015). "Disentangling Contagion among Sovereign CDS Spreads during the European Debt Crisis", Journal of Empirical Finance 32, 165-179.

CAPORIN, M., PELIZZON, L., RAVAZZOLO, F., and RIGOBON, R. (2013). "Measuring Sovereign Contagion in Europe", NBER Working Paper No. 18741

CHORDIA, T., ROLL, R., and SUBRAHMANYAM, A., (2000). "Commonality in Liquidity", Journal of Financial Economics, 56, 3-28.

CONSTANCIO, V. (2012). "Contagion and the European debt crisis", Financial Stability Review, 16, 109-123.

COUGHENHOUR, J.F., and SAAD, M.M. (2004). "Common Market Makers and Commonality in Liquidity", Journal of Financial Economics, 74, 37-69.Dieckmann, S. and Plank, T. (2012). "Default Risk of Advanced Economies: An Empirical Analysis of Credit Default Swaps during the Financial Crisis", Review of Finance, 16, 903-934.

DUFFIE D. (2010). "Is There a Case for Banning Short Speculation in Sovereign Bond Markets?" Banque de France Financial Stability Review, 14, 55-59.

EUROPEAN CENTRAL BANK. Credit Default Swaps and Counterparty Risk. August 2009.

GROSSMAN, R. and HANSEN, M. (2010). "CDS Spreads and Default Risk: Interpreting the Signals", Fitch Ratings Special Report. 27-43.

GARLEANU, N., PEDERSEN, L., and POTESHMAN, A. (2009), "Demand-Based Option Pricing", Review of Financial Studies 22 (10), 4259-4299.

GARMAN, M. B. (1976). "Market Microstructure". Journal of Financial Economics 3, 257-275.

GEHDE-TRAPP, M., GÜNDÜZ, Y., and NASEV, J. (2015). "The liquidity premium in CDS transaction prices: Do frictions matter?". Journal of Banking \& Finance 61, 184-205.

GISSLER, S. (2017) "Lockstep in Liquidity: Common Dealers and Co-Movement in Bond Liquidity". Journal of Financial Markets, 33, 1-21.

GONZÁLEZ-PÁRAMO, J. M. (2011), "Sovereign contagion in Europe". Distinguished Speaker Seminar of the European Economics and Financial Centre, London, 25 November 2011.

GREENE, W.H. (2011). Econometric Analysis. Prentice Hall.

HART, O., and ZINGALES, L. (2012) "A New Capital Regulation for Large Financial Institutions", American Law and Economic Association Review, 13, 453-490

HASAN, I., and WU, D. (2016) "How Large Banks Use CDS to Manage Risks: Bank-Firm-Level Evidence" Bank of Finland Research Discussion Paper $10-2016$

HILSCHER, J., POLLET, J. M., and WILSON, M. (2015) "Are Credit Default Swaps a Sideshow? Evidence that Information Flows from Equity to CDS markets". Journal of Financial and Quantitative Analysis, 50, 543-567.

Ho, T., Stoll, H., (1983). "The dynamics of dealer markets under competition", Journal of Finance, 38, 1053-1074.

KALBASKA, A., and GATKOWSKI, M. (2012). "Eurozone Sovereign Contagion: Evidence from the CDS Market (20052010)", Journal of Economic Behavior and Organization, 83, 657-673. 
KLINGLER, S., and LANDO, D. (2014) "Safe-Haven CDS Premia”, Available at SSRN: http://ssrn.com/abstract=2536632. LIN, J. C., and HOWE, J. S. (1990). "Insider trading in the OTC market". The Journal of Finance, 45, 1273-1284.

LONGSTAFF, F.A., PAN, J., PEDERSEN, J. P., AND SINGLETON, K. J. (2011). "How Sovereign Is Sovereign Credit Risk?", American Economic Journal: Macroeconomics, 3, 75-103.

LÓPEZ-ESPINOSA, G., MORENO, A., RUBIA, A., and VALDERRAMA, L. (2012). "Short-term Wholesale Funding and Systemic Risk: A Global CoVaR Approach". Journal of Banking and Finance, 36, 3150-3162.

LOU, D., YAN, H., and ZHANG, J. (2013). "Anticipated and repeated shocks in liquid markets". Review of Financial Studies, 26, 1891-1912.

MAYORDOMO, S., PENA, J. I., and SCHWARTZ, E., (2014) "Are All Credit Default Swap Databases Equal?", European Financial Management, 20, 677-713

MENGLE, D. (2010). "Concentration of OTC derivatives among major dealers", ISDA Research Notes.

O'HARA, M. and G. S. OLDFIELD (1986). "The Microeconomics of Market Making”. Journal of Financial and Quantitative Analysis 21, 361-376.

PAN, J., and SINGLETON, K. J. (2008) "Default and Recovery Implicit in the Term Structure of Sovereign CDS Spreads", Journal of Finance, 63, 2345-2384

PASQUARIELLO, P., and VEGA, C. (2015) "Strategic Cross-Trading in the U.S. Stock Market", Review of Finance, 19, 229-282.

QIU, J., and YU, F. (2012). "Endogenous Liquidity in Credit Derivatives”, Journal of Financial Economics, 103, 611-631.

Rodriguez-Moreno, M., and Peña, J. I. (2013). "Systemic Risk Measures: The Simpler the Better?", Journal of Banking \& Finance, 37, 1817-1831.

SHACHAR, O. (2013). "Exposing the exposed: Intermediation capacity in the credit default swap market". Working Paper. SHAN, S. C., TANG, D. Y., and YAN, H. (2016) "Credit Default Swaps and Bank Regulatory Capital”, Working Paper. SIRIWARDANE, E. N. (2014). "Concentrated Capital Losses and the Pricing of Corporate Credit Risk", NYU Working Paper.

Stoll, H. R. (1978). "The Supply of Dealer Services in Securities Markets". Journal of Finance 33, 1133-1151.

SUBRAHMANYAM, M. G., TANG, D. Y., and WANG, S. Q. (2014) "Does the Tail Wag the Dog?: The Effect of Credit Default Swaps on Credit Risk". Review of Financial Studies 27, 2927-2960.

Tang, D. Y., and Yan, H. (2015) "Understanding Transactions Prices in the Credit Default Swaps Market". Working Paper.

VOGEL, D. H., BANNIER, C. E., and HEIDORN, T. (2013). "Functions and Characteristics of Corporate and Sovereign CDS". Frankfurt School - Working Paper Series, 203.

YORULMAZER, T. (2013). "Has Financial Innovation Made the World Riskier? CDS, Regulatory Arbitrage and Systemic Risk". Available at SSRN: http://ssrn.com/abstract=2176493. 


\section{Figures and tables}

\section{Figure 1: Comovements in Sovereign CDS}

This figure depicts two measures of the comovement in sovereign CDS. Panel A illustrates the monthly correlation of the daily CDS log return $\left(\rho_{i j t}\right)$ for the considered 11 EMU countries (i.e., 55 different countrypairs). Panel B illustrates the monthly correlation of daily sovereign filtered CDS returns $\left(\rho_{i j t}^{*}\right)$ and constitutes our baseline measure of the comovements in sovereign CDS. The charts show the median correlation (dashed line), together with their $5^{\text {th }}$ and $95^{\text {th }}$ percentiles (shaded area) for the period January 2008 to October 2011. Daily CDS data comes from Markit.

\section{Panel A}

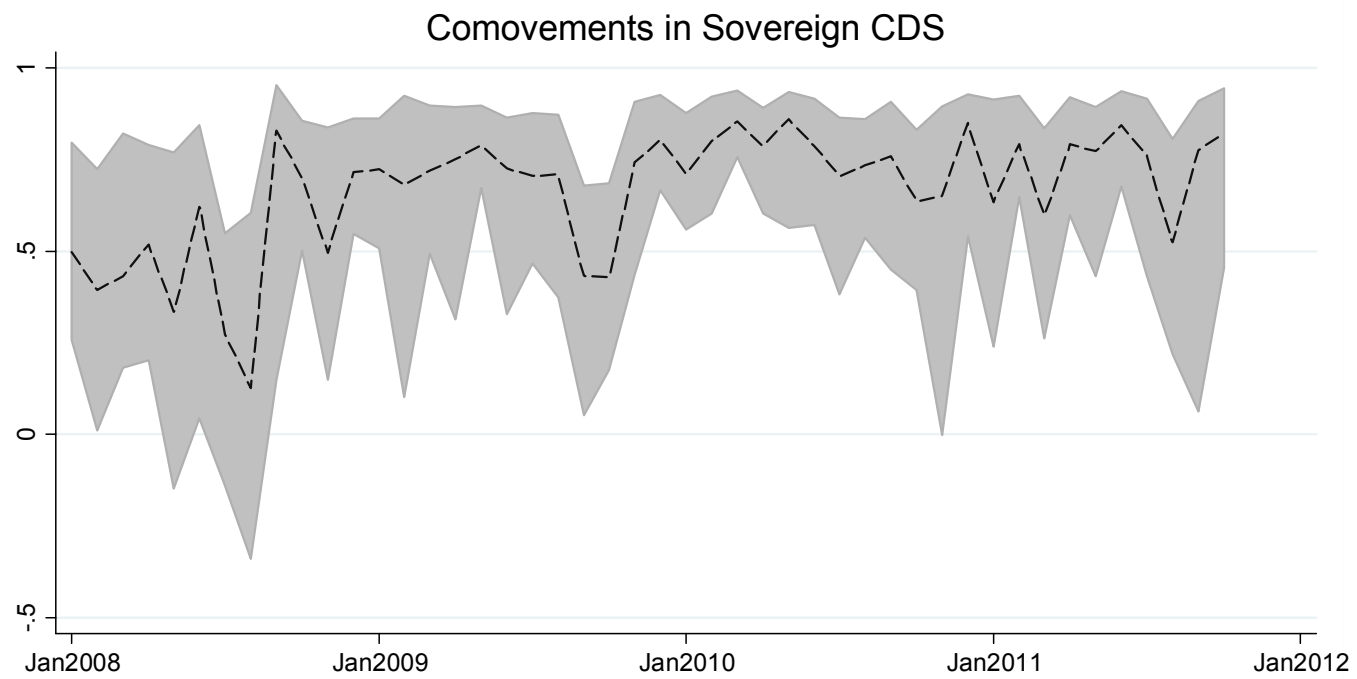

\section{Panel B}

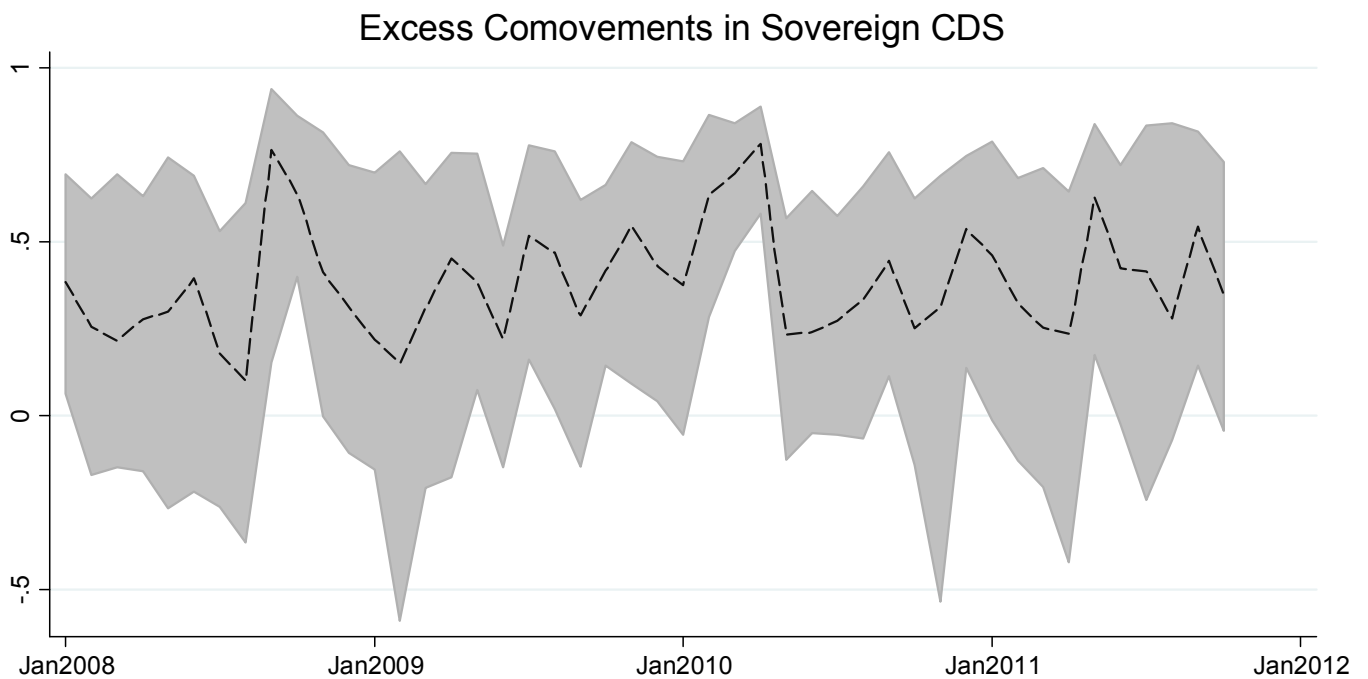




\section{Figure 2: Commonalities in Quotes}

This figure depicts the Commonalities in Quotes $\left(C Q_{i j t}\right)$ obtained as $C Q_{i j t}=\sum_{d=1}^{D_{t}} \omega_{d t} \operatorname{corr}\left(N Q_{i d t}, N Q_{j d t}\right)$, where $N Q_{\text {idt }}$ and $N Q_{j d t}$ are the number of daily quotes given to country $i$ and country $j$, respectively, by dealer $d$ in a given month $t$, and $D_{t}$ is the total number of dealers reporting quotes to both countries $i$ and $j$ in month $t$. The $C Q_{i j t}$ is a weighted average of the monthly correlation between the number of daily quotes reported by dealer $d$ to countries $i$ and $j$ in which the weight assigned to dealer $d$ in month $t\left(\omega_{d t}\right)$ is defined as the number of common quotes given by a dealer to countries $i$ and $j$ relative to the total number of number of common quotes to those countries. In the case that dealer $d$ does not report quotes to country $i$ on a certain date, we impute a value of zero for that date. The chart shows the median correlation (dashed line), together with their $5^{\text {th }}$ and $95^{\text {th }}$ percentiles (shaded area) for the period January 2008 to October 2011.

\section{Commonalities in Quotes}

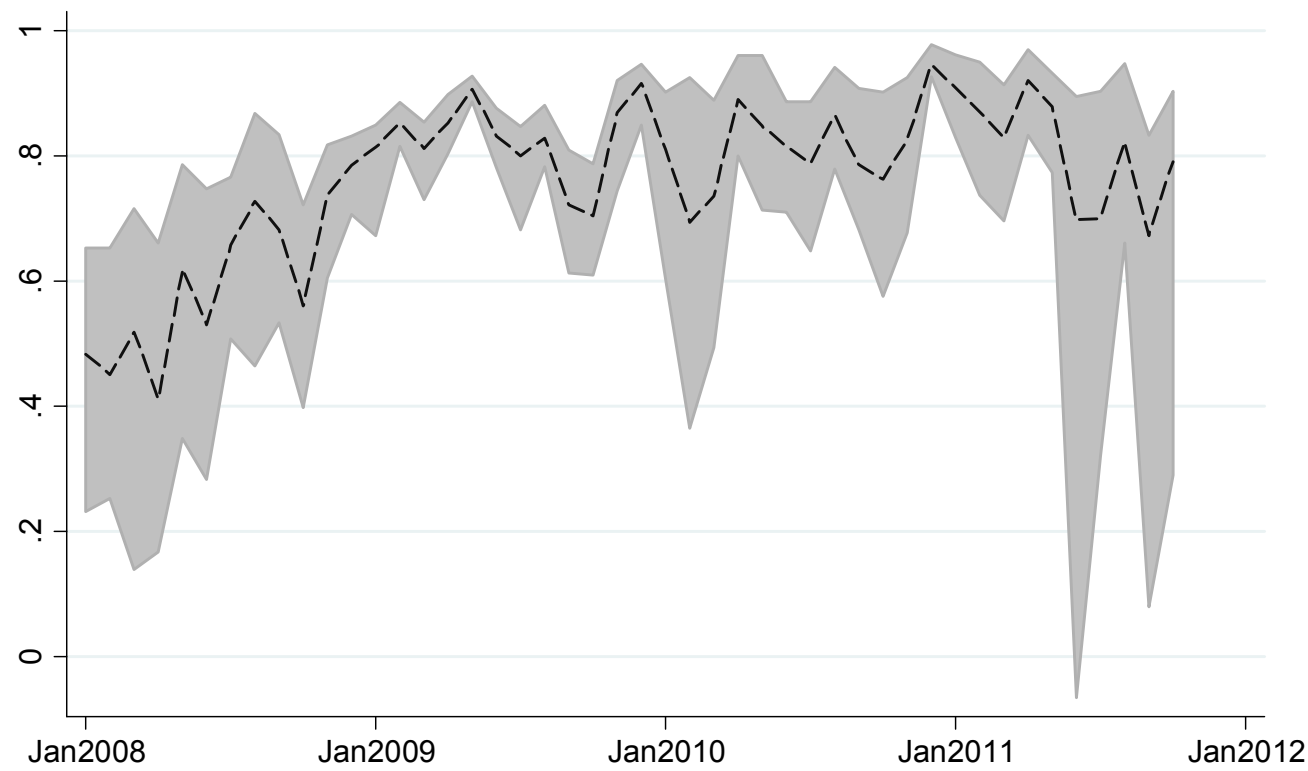


Table I: Summary Statistics

Table I contains the summary statistics of the final sample of CDS quotes and the dealers' activity. Panel A reports the total number of quotes and the total number of dealers reporting quotes as well as their daily averages for 11 EMU countries from January 2008 to October 2011 at the country level. Panel B aggregates countries in two areas (EMU and Non-EMU) and reports the number of countries in each area, the total number of quotes and the total number of dealers reporting quotes, as well as their daily averages per area for the sub-period January 2010 to October 2011. Panel C summarizes the total number of quotes per dealer and the dealer's market share for the 11 EMU countries from January 2008 to October 2011.

Panel A: Descriptive statistics. Sample: January 2008 - October 2011

\begin{tabular}{lrccc}
\hline & \multicolumn{2}{c}{ Number of Quotes } & \multicolumn{2}{c}{ Number of Dealers } \\
EMU Countries & Aggregate & Daily Average & Aggregate & Daily Average \\
\hline Austria & 448773 & 591 & 90 & 28 \\
Belgium & 449147 & 580 & 90 & 28 \\
Finland & 331887 & 464 & 90 & 27 \\
France & 469751 & 625 & 91 & 28 \\
Germany & 386181 & 521 & 89 & 27 \\
Greece & 598638 & 772 & 93 & 29 \\
Ireland & 606506 & 782 & 92 & 28 \\
Italy & 581538 & 731 & 91 & 28 \\
Netherlands & 347764 & 473 & 89 & 27 \\
Portugal & 624875 & 802 & 92 & 28 \\
Spain & 682032 & 862 & 93 & 28 \\
\hline
\end{tabular}

Panel B: Descriptive statistics. Sample: January 2010 - October 2011

\begin{tabular}{lccccc}
\hline Areas & Number of & \multicolumn{2}{c}{ Number of Quotes } & \multicolumn{2}{c}{ Number of Dealers } \\
& Countries & Aggregate & Daily Average & Aggregate & Daily Average \\
\hline Non-EMU & 39 & 4656079 & 8931 & 48 & 26 \\
EMU & 11 & 4803901 & 9216 & 53 & 29 \\
\hline
\end{tabular}

Panel C: Number of quotes distribution for EMU countries

\begin{tabular}{ccc}
\hline Dealer & \multicolumn{2}{c}{ Number of Quotes } \\
Top 10 & Share \\
\hline 1 & 303851 & $5.50 \%$ \\
2 & 298052 & $5.40 \%$ \\
3 & 274772 & $5.00 \%$ \\
4 & 268195 & $4.90 \%$ \\
5 & 264496 & $4.80 \%$ \\
6 & 262095 & $4.70 \%$ \\
7 & 240076 & $4.30 \%$ \\
8 & 221383 & $4.00 \%$ \\
9 & 204477 & $3.70 \%$ \\
10 & 200736 & $3.60 \%$ \\
\hline $1-10$ & 2538133 & $45.90 \%$ \\
$11-20$ & 1609411 & $29.10 \%$ \\
$21-30$ & 873379 & $15.80 \%$ \\
$31-40$ & 335378 & $6.10 \%$ \\
$41-50$ & 110119 & $2.00 \%$ \\
$51-95$ & 60672 & $1.10 \%$ \\
\hline
\end{tabular}




\section{Table II: Summary Statistics (cont'd)}

This table reports summary statistics on the daily CDS spread level (CDS), the daily CDS spread log return (CDS Log Ret.), the monthly correlation of the daily CDS log return $\left(\rho_{i j t}\right)$, the monthly correlation of daily sovereign filtered CDS returns $\left.\left(\rho_{i j t}^{*}\right)\right)$ for all pairs of the EMU countries, and the monthly Commonality in Quotes $\left(C Q_{i j t}\right)$ for such countries. Panel A reports the information for the $11 \mathrm{EMU}$ countries listed in Table I, while Panel B excludes Greece. Panels C and D break down the mean and standard deviation per year.

Panel C refers to the 11 EMU countries, and Panel D excludes Greece.

\begin{tabular}{|c|c|c|c|c|c|c|c|c|c|}
\hline \multicolumn{7}{|c|}{ Panel A: ALL EMU COUNTRIES } & & & \\
\hline Variable & Freq & Mean & $\mathrm{SD}$ & Min & Median & Max & & & \\
\hline CDS & Daily & 180 & 444 & 5 & 70 & 6986 & & & \\
\hline CDS Log Ret. & Daily & 0.00 & 0.05 & -0.49 & 0.00 & 0.49 & & & \\
\hline$\rho_{i j t}$ & Monthly & 0.65 & 0.26 & -0.58 & 0.72 & 0.98 & & & \\
\hline$\rho_{i j t}^{*}$ & Monthly & 0.30 & 0.27 & -0.70 & 0.32 & 0.93 & & & \\
\hline$C Q_{i j t}$ & Monthly & 0.75 & 0.17 & -0.15 & 0.79 & 0.98 & & & \\
\hline \multicolumn{7}{|c|}{ Panel B: ALL COUNTRIES but GREECE } & & & \\
\hline Variable & Freq & Mean & SD & Min & Median & Max & & & \\
\hline CDS & Daily & 122 & 171 & 5 & 65 & 1304 & & & \\
\hline CDS Log Ret. & Daily & 0.00 & 0.05 & -0.49 & 0.00 & 0.49 & & & \\
\hline$\rho_{i j t}$ & Monthly & 0.66 & 0.26 & -0.58 & 0.73 & 0.98 & & & \\
\hline$\rho_{i j t}^{*}$ & Monthly & 0.32 & 0.27 & -0.65 & 0.33 & 0.91 & & & \\
\hline$C Q_{i j t}$ & Monthly & 0.76 & 0.16 & 0.10 & 0.80 & 0.98 & & & \\
\hline \multicolumn{10}{|c|}{ Panel C: SUBPERIODS } \\
\hline & & \multicolumn{2}{|c|}{2008} & \multicolumn{2}{|c|}{2009} & \multicolumn{2}{|c|}{2010} & \multicolumn{2}{|c|}{2011} \\
\hline Variable & Freq & Mean & SD & Mean & SD & Mean & $\mathrm{SD}$ & Mean & SD \\
\hline CDS & Daily & 38 & 40 & 90 & 64 & 184 & 209 & 456 & 862 \\
\hline CDS Log Ret. & Daily & 0.01 & 0.05 & 0.00 & 0.05 & 0.00 & 0.05 & 0.00 & 0.04 \\
\hline$\rho_{i j t}$ & Monthly & 0.41 & 0.34 & 0.76 & 0.12 & 0.71 & 0.17 & 0.70 & 0.18 \\
\hline$\rho_{i j t}^{*}$ & Monthly & 0.30 & 0.28 & 0.30 & 0.26 & 0.33 & 0.27 & 0.27 & 0.28 \\
\hline$C Q_{i j t}$ & Monthly & 0.59 & 0.17 & 0.82 & 0.08 & 0.81 & 0.11 & 0.77 & 0.19 \\
\hline \multicolumn{10}{|c|}{ Panel D: SUBPERIODS (ALL b Gr) } \\
\hline & & \multicolumn{2}{|c|}{2008} & \multicolumn{2}{|c|}{2009} & \multicolumn{2}{|c|}{2010} & \multicolumn{2}{|c|}{2011} \\
\hline Variable & Freq & Mean & $\mathrm{SD}$ & Mean & SD & Mean & $\mathrm{SD}$ & Mean & SD \\
\hline CDS & Daily & 34 & 35 & 82 & 59 & 133 & 119 & 264 & 286 \\
\hline CDS Log Ret. & Daily & 0.01 & 0.05 & 0.00 & 0.05 & 0.00 & 0.05 & 0.00 & 0.04 \\
\hline$\rho_{i j t}$ & Monthly & 0.41 & 0.35 & 0.76 & 0.12 & 0.73 & 0.15 & 0.73 & 0.15 \\
\hline$\rho_{i j t}^{*}$ & Monthly & 0.30 & 0.28 & 0.31 & 0.27 & 0.35 & 0.27 & 0.31 & 0.27 \\
\hline$C Q_{i j t}$ & Monthly & 0.58 & 0.17 & 0.82 & 0.07 & 0.81 & 0.10 & 0.82 & 0.11 \\
\hline
\end{tabular}




\section{Table III: Commonality in Quotes and CDS Return Correlation}

This table reports the estimates of panel regressions of the monthly correlation of daily sovereign filtered CDS returns $\left(\rho_{i j t}^{*}\right.$ ), with the Fisher transformation applied, for the sample of 11 EMU countries listed in Table I, Panel A. The regressions are at the country-pair level (55 different country-pairs) for the period of January 2008 to October 2011 (46 months). The independent variables include the Commonality in Quotes $\left(C Q_{i j t}\right)$, which refers to the number of quotes given by dealers to both countries in the pair, and a set of controls, all of them in $t$. The Fisher transformation is also applied to $C Q_{i j t}$ and to the rest of controls that are correlation coefficients. Commonality in Quotes are obtained as $C Q_{i j t}=\sum_{d=1}^{D_{t}} \omega_{d t} \operatorname{corr}\left(N Q_{i d t}, N Q_{j d t}\right)$, where $N Q_{i d t}$ and $N Q_{j d t}$ are the number of daily quotes given to country $i$ and country $j$, respectively, by dealer $d$ in a given month $t$, and $D_{t}$ is the total number of dealers reporting quotes to both countries $i$ and $j$ in month $t$. The $C Q_{i j t}$ is a weighted average of the monthly correlation between the number of daily quotes reported by dealer $d$ to countries $i$ and $j$ in which the weight assigned to dealer $d$ in month $t\left(\omega_{d t}\right)$ is defined as the number of common quotes given by a dealer to countries $i$ and $j$ relative to the total number of number of common quotes to those countries. The control variables include country-pair specific variables and global factors. The set of country-pair variables and global factors are self-explanatory in the way they are labeled in the table and in the body of the text. Column (1)-(2) report the results for equation (4) without and with the Commonality in Quotes $\left(C Q_{i j t}\right)$ variable, respectively. Standard errors in brackets are double-clustered at the country-pair and month level. *, **, and *** indicate statistical significance at the 10\%,5\%, and $1 \%$ levels, respectively. The economic impact of the variables in the baseline results obtained in column (2) is reported in column (3). It is obtained from the product of the estimated coefficient and one standard deviation of the independent variable.

\begin{tabular}{|c|c|c|c|c|}
\hline \multirow[b]{2}{*}{ VARIABLES } & & \multicolumn{3}{|c|}{$\begin{array}{c}\text { Dep. Variable t: ZCorrelation of filtered daily } \\
\text { CDS Log Ret. }\end{array}$} \\
\hline & & (1) & (2) & (3) \\
\hline \multicolumn{2}{|l|}{$\mathrm{ZCQ} t$} & & $\begin{array}{l}0.139^{\star * \star} \\
{[0.048]}\end{array}$ & 0.052 \\
\hline \multirow{4}{*}{$\begin{array}{l}\text { Pair/Country } \\
\text { Specific } \\
\text { Variables }\end{array}$} & ZCorr. Country Banks CDS Log Ret. t & $\begin{array}{c}0.033 \\
{[0.031]}\end{array}$ & $\begin{array}{c}0.032 \\
{[0.031]}\end{array}$ & 0.014 \\
\hline & ZCorr. CDS Relative Bid-Ask $\mathrm{t}$ & $\begin{array}{l}0.131^{\star \star \star} \\
{[0.029]}\end{array}$ & $\begin{array}{l}0.108^{\star \star \star} \\
{[0.030]}\end{array}$ & 0.050 \\
\hline & Abs|Deficit to GDPi - Deficit to GDPj|t & $\begin{array}{l}-0.005^{\star \star \star} \\
{[0.002]}\end{array}$ & $\begin{array}{c}-0.005^{\star \star \star} \\
{[0.001]}\end{array}$ & -0.030 \\
\hline & Abs|Debt to GDPi - Debt to GDPj| t & $\begin{array}{l}-0.001^{*} \\
{[0.001]} \\
\end{array}$ & $\begin{array}{l}-0.001^{*} \\
{[0.001]}\end{array}$ & -0.020 \\
\hline \multirow{6}{*}{$\begin{array}{l}\text { Global } \\
\text { Variables }\end{array}$} & & & & \\
\hline & $\Delta$ Log Euribor-OIS $_{t}$ & $\begin{array}{l}0.203^{\star} \\
{[0.104]}\end{array}$ & $\begin{array}{l}0.192^{*} \\
{[0.106]}\end{array}$ & 0.046 \\
\hline & $\Delta$ Log EA Treasury Yield $t$ & $\begin{array}{l}-0.478 \\
{[0.360]}\end{array}$ & $\begin{array}{l}-0.478 \\
{[0.400]}\end{array}$ & -0.022 \\
\hline & $\Delta$ Log EA Investment Grade Spread $\mathrm{t}$ & $\begin{array}{l}-0.101 \\
{[0.181]}\end{array}$ & $\begin{array}{l}-0.042 \\
{[0.186]}\end{array}$ & -0.006 \\
\hline & $\Delta$ Log Counterparty $_{\mathrm{t}}$ & $\begin{array}{c}0.144 \\
{[0.193]}\end{array}$ & $\begin{array}{c}0.143 \\
{[0.202]}\end{array}$ & 0.030 \\
\hline & $\Delta$ Log EUROSTOXX50 t & $\begin{array}{c}0.301 \\
{[0.537]}\end{array}$ & $\begin{array}{c}0.191 \\
{[0.576]}\end{array}$ & 0.012 \\
\hline \multicolumn{2}{|l|}{ Constant } & $\begin{array}{l}0.318^{\star \star *} \\
{[0.039]}\end{array}$ & $\begin{array}{l}0.170^{\star *} \\
{[0.070]}\end{array}$ & \\
\hline \multirow{2}{*}{\multicolumn{2}{|c|}{$\begin{array}{l}\text { Observations } \\
\text { R-squared }\end{array}$}} & 2,475 & 2,475 & \\
\hline & & 0.086 & 0.106 & \\
\hline
\end{tabular}


Table IV: Commonality in Quotes and CDS Return Correlation (cont'd)

Table IV shows the estimates of the regressions similar to column (2) in Table III, but when Greece is excluded from the sample (column (1)) and two different subperiods are analyzed: January 2008 to November 2009 in column (2), and December 2009 to October 2011 in column (3). Everything else remains as in Table III.

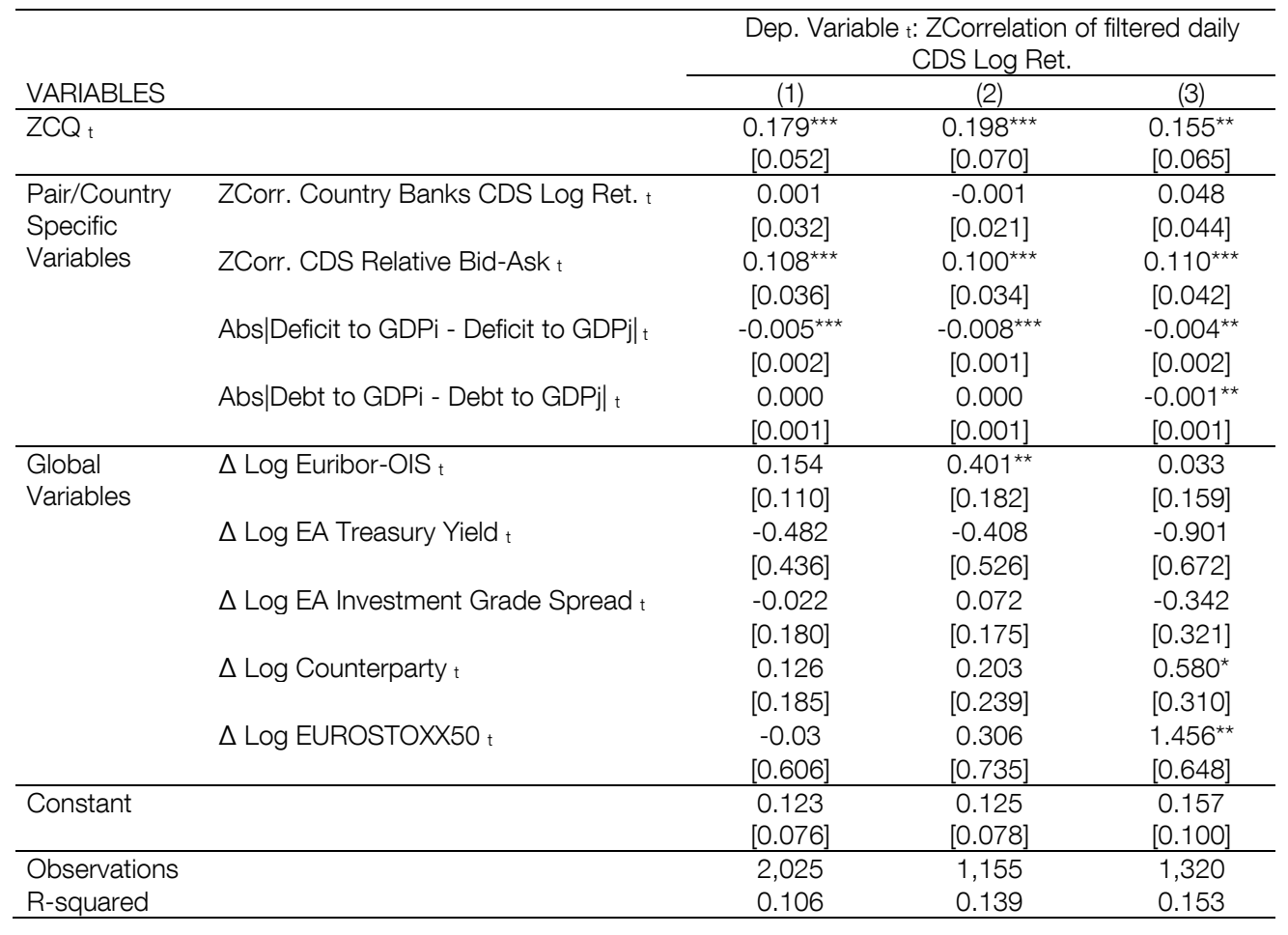




\section{Table V: Robustness Tests and Extensions. Alternative Frequencies}

and Alternative Sample of Countries

Table $\mathrm{V}$ reports the panel estimates of several variations in the baseline analysis (equation (4)). Column (1) reports the panel estimates of a regression analysis in which the variables are defined at weekly frequency. For instance, the Commonality in Quotes is obtained as in equation (1), but in this case we compute weekly correlations (Fisher transformation applied) from the number of quotes per day. The same procedure is applied to the rest of correlation variables, and for the global variables we take the weekly average. For the remaining independent variables, the absolute differences in the ratios of debt and deficit to GDP for a given pair of countries are those used in Table III and have a quarterly frequency. This analysis is performed for the sample of 55 pairs of EMU countries, and for the period January 2008 - October 2011. The results in column (2) are obtained from a similar regression at weekly frequency in which all the explanatory variables are lagged one week. Column (3) reports panel estimates of monthly regressions of the correlation of daily sovereign filtered CDS returns in month $t$ (Fisher transformation applied) for the sample of 50 countries across the world (11 EMU and 39 non-EMU countries). The regressions are at the countrypair level (820 different pairs) for the period of January 2010 to October 2011. All other controls are as in the baseline analysis (Table III), apart from the correlation of country banks' CDS log returns, which, due to the lack of information, is substituted by the absolute difference of bank nonperforming loans to total gross loans, defined on an annual basis. Standard errors in brackets are double-clustered at the country-pair and day level. ${ }^{*}{ }^{* \star}$, and ${ }^{\star \star \star}$ indicate statistical significance at the $10 \%, 5 \%$, and $1 \%$ levels, respectively.

\begin{tabular}{lccc}
\hline & \multicolumn{3}{c}{ Dep. Variable $\mathrm{t}:$ ZCorrelation of filtered daily CDS Log } \\
\cline { 2 - 4 } VARIABLES & \multicolumn{3}{c}{ Ret. } \\
\cline { 2 - 4 } ZCQ $t$ & $0.104^{* \star}$ & $(2)$ & $(3)$ \\
\hline Global Factors & {$[0.052]$} & 0.054 & $0.352^{* \star}$ \\
Country/Pair Factors & YES & YES & YES \\
Constant & YES & YES & YES \\
\hline Observations & YES & YES & YES \\
R-squared & 9,897 & 9,842 & 15,310 \\
\hline
\end{tabular}




\section{Table VI: Robustness Tests and Extensions. Dealing with the Lack of Trading}

This table reports the estimates of panel regressions of the monthly correlation of daily sovereign filtered CDS returns $\left(\rho_{i j t}^{*}\right)$, with the Fisher transformation applied, for alternative samples of countries to deal with the lack of trading in some of their CDS contracts. Results in columns (1) and (2) are obtained from the sample of EMU countries, and using all the contracts and months for which there is information in DTCC (i.e., November 2008 - October 2011). Results in columns (3) - (5) are obtained using the whole universe of sovereign CDS for a time period that spans from January 2010 to October 2011, due to the availability of data for the non-EMU countries. The results reported in columns (1) and (3) are obtained using all the contracts and months for which there is information in DTCC. In columns (2) and (4) we remove from the sample the most inactively traded countries. We consider as actively traded contracts those ones traded every week in a given month, according to the information in DTCC, and as inactively traded contracts those in which there is not trading in at least one week of the month. Finally, in columns (5) and (6) we propose a new classification to define actively and non-actively traded countries. Specifically, we compute for each month the 33th and 66th percentiles from the distribution of the number of contracts traded on the sample of countries. We then define a contract as non-actively traded if the number of traded contracts in that country in that month is below the 33th percentile, whereas actively traded contracts are those that are above the 66th percentile. Column (5) corresponds to the analysis of pairs formed by non-actively traded countries, and column (6) corresponds to pairs formed by a country that is actively traded and another one that is not. The Fisher transformation is applied to all the variables that are correlation coefficients (i.e., the dependent variable, the variable of interest, and several controls). All columns contain the economic impact of the Commonality in Quotes for each specification that is obtained from the product of the estimated coefficient and one standard deviation of the independent variable. Standard errors in brackets are double-clustered at the country-pair and monthly level. *, ${ }^{* *}$, and ${ }^{* \star *}$ indicate statistical significance at the $10 \%, 5 \%$, and $1 \%$ levels, respectively.

\begin{tabular}{lcccccc}
\hline \multicolumn{6}{c}{ Dep. Variable t: ZCorrelation of filtered daily CDS Log Ret. } \\
VARIABLES & $(1)$ & $(2)$ & $(3)$ & $(4)$ & $(5)$ & $(6)$ \\
\hline ZCQ $\mathrm{t}$ & $0.177^{\star \star \star}$ & $0.187^{\star \star \star}$ & $0.352^{\star \star \star}$ & $0.383^{\star \star \star}$ & $0.330^{\star \star \star}$ & $0.308^{\star \star \star}$ \\
& {$[0.060]$} & {$[0.062]$} & {$[0.038]$} & {$[0.037]$} & {$[0.044]$} & {$[0.034]$} \\
\hline Global Factors & YES & YES & YES & YES & YES & YES \\
Country/Pair Factors & YES & YES & YES & YES & YES & YES \\
Constant & YES & YES & YES & YES & YES & YES \\
\hline Economic Impact & 0.058 & 0.063 & 0.141 & 0.153 & 0.151 & 0.117 \\
\hline Observations & 1,980 & 1,713 & 15,310 & 12,299 & 1,380 & 3,219 \\
R-squared & 0.098 & 0.107 & 0.217 & 0.243 & 0.256 & 0.168 \\
\hline
\end{tabular}




\section{Table VII: Robustness Tests and Extensions. Dealers Characteristics}

and Trading Behavior

This table provides additional evidence on the comovements in returns due to common dealers based on the sample of 50 countries for the period January 2010-October 2011. We consider that a given pair of CDS has a common dealer if the specialist in both countries is the same. We classify market makers as specialists depending on their quoting activity. We use information on the number of contracts traded in a given week from DTCC, and assign the best bid and ask quotes to potential purchases and sales of CDS. We first define the purchases and sales for each dealer by ordering their bid and ask prices in a type of limit order book, assuming that the highest (lowest) bid (ask) prices within a given week are the most likely to end up in trades. This strategy enables us to "infer" the number of contracts traded by each dealer each week, and to add them at monthly level so that we can classify them as specialists in a given country. We also order the best bid and ask prices at daily level and assume that the best bid and ask prices in a given day are the ones that are more likely to be tradable. To obtain the number of daily trades, we divide the number of trades in a given week by the number of banking days in that week. The daily trades of a dealer are then aggregated at the monthly level to classify them as specialist, depending on their trading activity in each country. We consider three alternative methods to classify dealers as specialists: (i) those whose average number of monthly trades, independently on whether they are purchases or sales, is the highest across all dealers; (ii) those with the highest number of accumulated trades independently on whether they are purchases or sales; (iii) those that have been the most active traders in the highest number of weeks. To obtain the role of common dealership on CDS comovements we propose an extended market model in which the dependent variable is the CDS return, which is regressed on a market factor and a dealer/specialist factor (see equation \# for further details). Each column reports the average estimate for each of the two factors joint, with the t-statistic associated to each test (to see if the average estimate for each factor is statistically different from zero). Columns (1), (2), and (3) contain the results obtained for the definitions of specialist (i), (ii), and (iii), respectively, for the case in which the trades are assigned on a weekly basis. Columns (4), (5), and (6) contain the results obtained for the definitions of specialist (i), (ii), and (iii), respectively, for the case in which the trades are assigned on a daily basis. ${ }^{*},{ }^{\star *}$, and ${ }^{\star \star *}$ indicate statistical significance at the $10 \%, 5 \%$, and $1 \%$ levels, respectively.

\begin{tabular}{lcccccc}
\hline & \multicolumn{5}{c}{ Weekly } & \multicolumn{3}{c}{ Daily } \\
& $(1)$ & $(2)$ & $(3)$ & $(4)$ & $(5)$ & $(6)$ \\
\hline $\begin{array}{l}\text { Specialist } \\
\text { Average Beta }\end{array}$ & 0.637 & 0.870 & 0.750 & 0.615 & 0.757 & 0.757 \\
t-stat & 5.823 & 8.298 & 6.777 & 7.827 & 11.442 & 8.366 \\
Market & & & & & & \\
Average Beta & 0.330 & 0.095 & 0.219 & 0.353 & 0.206 & 0.209 \\
t-stat & 3.115 & 0.957 & 1.956 & 4.684 & 3.462 & 2.327 \\
\hline Average Adj. R2 & 0.468 & 0.490 & 0.483 & 0.481 & 0.497 & 0.506 \\
\hline
\end{tabular}




\section{Table VIII: Dealer's trading pressure}

Table VIII reports the estimates of panel regressions on the monthly correlation of daily sovereign filtered CDS returns $\left(\rho_{i j t}^{*}\right)$, with the Fisher transformation applied, for the sample of $11 \mathrm{EMU}$ countries listed in Table I, Panel A. The regressions are at the country-pair level (55 different country-pairs) for the period of January 2008 to October 2011 (46 months). The dependent variable in this table is the one employed in Table III. The novelty here is that the variable Commonality in Quotes is broken down according to the trading pressure faced by each dealer in each pair of countries. According to equation (3), we consider the commonalities obtained from dealers quoting ask and bid prices above the $66^{\text {th }}$ percentile in the two countries (i.e., dealers facing buying pressure, $C Q_{i j t}^{B}$ ) separately from those obtained from dealers quoting ask and bid prices below the $33^{\text {rd }}$ percentile (i.e., dealers facing selling pressure, $C Q_{i j t}^{S}$ ). Finally, Commonality not from Buying or Selling Pressure $\left(C Q_{i j t}^{N B S}\right)$ is computed with those dealers that are not in the $B$ or $S$ category. Column (1) reports the results obtained from the joint use of the three types of commonalities (Fisher transformation applied). In addition, to capture the effect of dealers' market power, we further break down the variable $C Q_{i j t}^{B}$ into two, according to the dealer's size. We define active dealers facing buying pressure in a given month as those whose total number of quotes to a given pair of countries is above the median $\left(\mathrm{CQ}_{\mathrm{ijt}}^{\mathrm{B}>p c t l 50}\right)$ of the distribution of the total number of quotes per pair and dealer. Column (2) contains the results obtained from the joint use of the four types of commonalities. Finally, in column (3), we break down the variable Commonality in Quotes into three variables (Fisher transformation applied), with a new definition of trading pressure based on dealers' net trading positions. To define the trading position we use information from DTCC on the number of trades per week and then assign as trades the best bid and ask quotes in each week, that are then aggregated for each dealer at monthly level. A dealer faces buying (selling) pressure in given month when his/her net trading position in a given month is positive (negative), whereas a net trading position equal to zero indicates the absence of both buying and selling pressure. In the interest of brevity, and because the results are consistent with those of Table III, we only report the coefficients for the new specifications of Commonality in Quotes variables. Standard errors in brackets are double-clustered at the country-pair and month level. *, ${ }^{* *}$, and ${ }^{* *}$ indicate statistical significance at the $10 \%, 5 \%$, and $1 \%$ levels, respectively.

\begin{tabular}{|c|c|c|c|}
\hline \multirow[b]{2}{*}{ VARIABLES } & \multicolumn{3}{|c|}{ Dep. Variable t: ZCorrelation of filtered daily CDS Log Ret } \\
\hline & (1) & (2) & (3) \\
\hline \multirow[t]{2}{*}{$C Q_{t}^{S}$} & 0.071 & 0.075 & 0.010 \\
\hline & {$[0.050]$} & [0.050] & [0.062] \\
\hline \multirow[t]{2}{*}{$\mathrm{CQ}_{\mathrm{t}}^{\mathrm{NoB}-\mathrm{NoS}}$} & -0.068 & -0.054 & 0.034 \\
\hline & [0.084] & [0.085] & [0.033] \\
\hline \multirow[t]{2}{*}{$\mathrm{CQ}_{\mathrm{t}}^{\mathrm{B}}$} & $0.115^{\star \star}$ & & $0.118^{\star *}$ \\
\hline & [0.046] & & {$[0.056]$} \\
\hline \multirow[t]{2}{*}{$\mathrm{CQ}_{\mathrm{t}}^{\mathrm{B},>\mathrm{pct} 150}$} & & $0.071^{* *}$ & \\
\hline & & [0.036] & \\
\hline \multirow[t]{2}{*}{$\mathrm{CQ}_{\mathrm{t}}^{\mathrm{B},<\mathrm{pct|150}}$} & & 0.022 & \\
\hline & & [0.034] & \\
\hline Global Factors & YES & YES & YES \\
\hline Country/Pair Factors & YES & YES & YES \\
\hline Constant & YES & YES & YES \\
\hline Observations & 2,160 & 2,160 & 1,707 \\
\hline R-squared & 0.101 & 0.099 & 0.081 \\
\hline
\end{tabular}




\section{Table IX: Accounting for Endogeneity}

Table IX reports the results of a set of analyses to rule out any potential endogeneity problem. Columns (1) (2) report the results of the instrumental variable analysis. This analysis is based on a variation of equation (4), in which we instrument the Commonality in Quotes from Buying Pressure $\left(C Q_{i j t}^{B}\right)$. For each pair of countries, the instrument is defined as the average quarterly Tier 1 capital ratio (Av Tier 1 ) of a subset of international banks whose headquarters are not located in any of the two countries/economic areas forming the pair. Additionally, we require that the domestic banks of a given country exhibit a positive exposure to the official sector of both countries forming the pair, and exclude banks with subsidiaries in any of the two countries in the pair. The analysis is performed on a subset of pairs of non-OECD countries with rating category equal or lower than A+ (positive risk weight) from the whole universe of sovereign CDS described in Panel B of Table I. Information of the Tier 1 capital ratio is released on a quarterly basis, so the analysis relies on quarterly observations for the period 2010-2011 (and hence the dependent and control variables are the ones in Table III, but on a quarterly basis). Column (1) reports the results for the instrumental variable analysis. In column (2) we check whether the instrument in column (1) is uncorrelated with the error term. To that aim, we propose an equation that is not exactly identified, by including the squared of the instrument as an additional instrumental variable. In column (3) we perform a new instrumental approach in which we use the average Tier 1 calculated for each of pair countries lagged one quarter. In column (4) we filter even more our sample in such a way that we restrict the IV analysis performed in column (2) to a sample of countries with an average CDS excess correlation that is not statistically different from zero. Column (5) reports the results obtained from an alternative methodology to deal with endogeneity. This column contains the estimates of panel regressions on the monthly correlation of daily sovereign filtered CDS returns for the sample of $11 \mathrm{EMU}$ countries listed in Table I, Panel A. The novelty here is the use of the Commonality in Quotes that is due to dealers facing buying pressure filtered from the past CDS correlations $\left(F I L T . C Q_{i j t}^{B}\right)$. The dependent and control variables are the ones reported in Table III. In the interest of brevity, and because the results are consistent with those of Table III, we only report the coefficients for the new specifications of Commonality in Quotes. The Fisher transformation is applied to all the variables that are correlation coefficients (i.e., the dependent variable, the variable of interest, and several controls). *, **, and ${ }^{* \star *}$ indicate statistical significance at the $10 \%, 5 \%$, and $1 \%$ levels, respectively.

\begin{tabular}{|c|c|c|c|c|c|}
\hline \multirow[b]{2}{*}{ VARIABLES } & \multicolumn{5}{|c|}{ Dep. Variable t: ZCorrelation of filtered daily CDS Log Ret. } \\
\hline & (1) & (2) & (3) & (4) & (5) \\
\hline INST. ZCQ ${ }^{\mathrm{B}}$ & $\begin{array}{l}0.758^{\star \star} \\
{[0.346]}\end{array}$ & $\begin{array}{l}0.881^{\star \star \star} \\
{[0.262]}\end{array}$ & $\begin{array}{l}0.893^{\star \star \star} \\
{[0.264]}\end{array}$ & $\begin{array}{l}0.447^{*} \\
{[0.255]}\end{array}$ & \\
\hline FILT. ZCQ ${ }_{t}^{B}$ & & & & & $\begin{array}{l}0.200^{* *} \\
{[0.078]}\end{array}$ \\
\hline Global Factors & YES & YES & YES & YES & YES \\
\hline Country/Pair Factors & YES & YES & YES & YES & YES \\
\hline Constant & YES & YES & YES & YES & YES \\
\hline Observations & 569 & 569 & 467 & 445 & 2,098 \\
\hline Number of pairs & 102 & 102 & 91 & 99 & 54 \\
\hline R-squared & - & - & - & - & 0.101 \\
\hline $\begin{array}{l}\text { Underidentification test } \\
\text { (Kleibergen-Paap rk LM statistic) } \\
\text { Chi-sq(1) P-val }\end{array}$ & $\begin{array}{l}6.921 \\
0.009\end{array}$ & $\begin{array}{l}13.868 \\
0.001\end{array}$ & $\begin{array}{l}15.145 \\
0.001\end{array}$ & $\begin{array}{l}5.617 \\
0.060\end{array}$ & $\begin{array}{l}- \\
-\end{array}$ \\
\hline $\begin{array}{l}\text { Overidentification test (Hansen J } \\
\text { statistic) }\end{array}$ & Eq. exactly & 0.226 & 0.018 & 0.609 & - \\
\hline Chi-sq(1) P-val & & 0.635 & 0.894 & 0.435 & - \\
\hline Instrumented: & $\mathrm{ZCQ}_{\mathrm{t}}^{\mathrm{B}}$ & $\mathrm{ZCQ}_{\mathrm{t}}^{\mathrm{B}}$ & $\mathrm{ZCQ}_{\mathrm{t}}^{\mathrm{B}}$ & $\mathrm{ZCQ}_{\mathrm{t}}^{\mathrm{B}}$ & - \\
\hline Excluded instruments: & Avg. Tier $1_{t}$ & $\begin{array}{l}\text { Avg. Tier1 } 1_{t} \\
\text { Avg. Tier1 }{ }^{2} t \\
\end{array}$ & $\begin{array}{l}\text { Avg. Tier1 } 1_{\mathrm{t}-1} \\
{\text { Avg. Tier1 } 1_{\mathrm{t}-1}}\end{array}$ & $\begin{array}{l}\text { Avg. Tier } 1_{t} \\
\text { Avg. Tier } 1^{2} t \\
\end{array}$ & - \\
\hline First stage IV approach & $\begin{array}{l}\text { Instrumented } \\
\text { Variable t: } \\
\text { ZCQt }^{\mathrm{B}}\end{array}$ & & & & \\
\hline Instrument: Avg. Tier1 & $\begin{array}{l}0.0413^{\star \star} \\
{[0.016]}\end{array}$ & & & & \\
\hline
\end{tabular}




\title{
BANCO DE ESPAÑA PUBLICATIONS
}

\author{
WORKING PAPERS
}

1601 CHRISTIAN CASTRO, ÁNGEL ESTRADA and JORGE MARTÍNEZ: The countercyclical capital buffer in Spain: an analysis of key guiding indicators.

1602 TRINO-MANUEL ÑíGUEZ and JAVIER PEROTE: Multivariate moments expansion density: application of the dynamic equicorrelation model.

1603 ALBERTO FUERTES and JOSÉ MARÍA SERENA: How firms borrow in international bond markets: securities regulation and market segmentation.

1604 ENRIQUE ALBEROLA, IVÁN KATARYNIUK, ÁNGEL MELGUIZO and RENÉ OROZCO: Fiscal policy and the cycle in Latin America: the role of financing conditions and fiscal rules.

1605 ANA LAMO, ENRIQUE MORAL-BENITO and JAVIER J. PÉREZ: Does slack influence public and private labour market interactions?

1606 FRUCTUOSO BORRALLO, IGNACIO HERNANDO and JAVIER VALLÉS: The effects of US unconventional monetary policies in Latin America.

1607 VINCENZO MERELLA and DANIEL SANTABÁRBARA: Do the rich (really) consume higher-quality goods? Evidence from international trade data.

1608 CARMEN BROTO and MATÍAS LAMAS: Measuring market liquidity in US fixed income markets: a new synthetic indicator.

1609 MANUEL GARCÍA-SANTANA, ENRIQUE MORAL-BENITO, JOSEP PIJOAN-MAS and ROBERTO RAMOS: Growing like Spain: 1995-2007

1610 MIGUEL GARCÍA-POSADA and RAQUEL VEGAS: Las reformas de la Ley Concursal durante la Gran Recesión.

1611 LUNA AZAHARA ROMO GONZÁLEZ: The drivers of European banks' US dollar debt issuance: opportunistic funding in times of crisis?

1612 CELESTINO GIRÓN, MARTA MORANO, ENRIQUE M. QUILIS, DANIEL SANTABÁRBARA and CARLOS TORREGROSA: Modelling interest payments for macroeconomic assessment.

1613 ENRIQUE MORAL-BENITO: Growing by learning: firm-level evidence on the size-productivity nexus.

1614 JAIME MARTÍNEZ-MARTíN: Breaking down world trade elasticities: a panel ECM approach.

1615 ALESSANDRO GALESI and OMAR RACHEDI: Structural transformation, services deepening, and the transmission of monetary policy.

1616 BING XU, ADRIAN VAN RIXTEL and HONGLIN WANG: Do banks extract informational rents through collateral?

1617 MIHÁLY TAMÁS BORSI: Credit contractions and unemployment.

1618 MIHÁLY TAMÁS BORSI: Fiscal multipliers across the credit cycle.

1619 GABRIELE FIORENTINI, ALESSANDRO GALESI and ENRIQUE SENTANA: A spectral EM algorithm for dynamic factor models.

1620 FRANCISCO MARTÍ and JAVIER J. PÉREZ: Spanish public finances through the financial crisis.

1621 ADRIAN VAN RIXTEL, LUNA ROMO GONZÁLEZ and JING YANG: The determinants of long-term debt issuance by European banks: evidence of two crises.

1622 JAVIER ANDRÉS, ÓSCAR ARCE and CARLOS THOMAS: When fiscal consolidation meets private deleveraging.

1623 CARLOS SANZ: The effect of electoral systems on voter turnout: evidence from a natural experiment.

1624 GALO NUÑO and CARLOS THOMAS: Optimal monetary policy with heterogeneous agents.

1625 MARÍA DOLORES GADEA, ANA GÓMEZ-LOSCOS and ANTONIO MONTAÑÉS: Oil price and economic growth: a long story?

1626 PAUL DE GRAUWE and EDDIE GERBA: Stock market cycles and supply side dynamics: two worlds, one vision?

1627 RICARDO GIMENO and EVA ORTEGA: The evolution of inflation expectations in euro area markets.

1628 SUSANA PÁRRAGA RODRÍGUEZ: The dynamic effect of public expenditure shocks in the United States.

1629 SUSANA PÁRRAGA RODRÍGUEZ: The aggregate effects of government incometransfer shocks - EU evidence.

1630 JUAN S. MORA-SANGUINETTI, MARTA MARTÍNEZ-MATUTE and MIGUEL GARCÍA-POSADA: Credit, crisis and contract enforcement: evidence from the Spanish loan market. 
1631 PABLO BURRIEL and ALESSANDRO GALESI: Uncovering the heterogeneous effects of ECB unconventional monetary policies across euro area countries.

1632 MAR DELGADO TÉLLEZ, VÍCTOR D. LLEDÓ and JAVIER J. PÉREZ: On the determinants of fiscal non-compliance: an empirical analysis of Spain's regions.

1633 OMAR RACHEDI: Portfolio rebalancing and asset pricing with heterogeneous inattention.

1634 JUAN DE LUCIO, RAÚL MÍNGUEZ, ASIER MINONDO and FRANCISCO REQUENA: The variation of export prices across and within firms.

1635 JUAN FRANCISCO JIMENO, AITOR LACUESTA, MARTA MARTÍNEZ-MATUTE and ERNESTO VILLANUEVA: Education, labour market experience and cognitive skills: evidence from PIAAC.

1701 JAVIER ANDRÉS, JAVIER J. PÉREZ and JUAN A. ROJAS: Implicit public debt thresholds: an empirical exercise for the case of Spain.

1702 LUIS J. ÁLVAREZ: Business cycle estimation with high-pass and band-pass local polynomial regression.

1703 ENRIQUE MORAL-BENITO, PAUL ALLISON and RICHARD WILLIAMS: Dynamic panel data modelling using maximum likelihood: an alternative to Arellano-Bond.

1704 MIKEL BEDAYO: Creating associations as a substitute for direct bank credit. Evidence from Belgium.

1705 MARÍA DOLORES GADEA-RIVAS, ANA GÓMEZ-LOSCOS and DANILO LEIVA-LEON: The evolution of regiona economic interlinkages in Europe.

1706 ESTEBAN GARCÍA-MIRALLES: The crucial role of social welfare criteria for optimal inheritance taxation.

1707 MÓNICA CORREA-LÓPEZ and RAFAEL DOMÉNECH: Service regulations, input prices and export volumes: evidence from a panel of manufacturing firms.

1708 MARÍA DOLORES GADEA, ANA GÓMEZ-LOSCOS and GABRIEL PÉREZ-QUIRÓS: Dissecting US recoveries.

1709 CARLOS SANZ: Direct democracy and government size: evidence from Spain.

1710 HENRIQUE S. BASSO and JAMES COSTAIN: Fiscal delegation in a monetary union: instrument assignment and stabilization properties.

1711 IVÁN KATARYNIUK and JAIME MARTÍNEZ-MARTÍN: TFP growth and commodity prices in emerging economies.

1712 SEBASTIAN GECHERT, CHRISTOPH PAETZ and PALOMA VILLANUEVA: Top-down vs. bottom-up? Reconciling the effects of tax and transfer shocks on output.

1713 KNUT ARE AASTVEIT, FRANCESCO FURLANETTO and FRANCESCA LORIA: Has the Fed responded to house and stock prices? A time-varying analysis.

1714 FÁTIMA HERRANZ GONZÁLEZ and CARMEN MARTÍNEZ-CARRASCAL: The impact of firms' financial position on fixed investment and employment. An analysis for Spain.

1715 SERGIO MAYORDOMO, ANTONIO MORENO, STEVEN ONGENA and MARÍA RODRÍGUEZ-MORENO: "Keeping it personal" or "getting real"? On the drivers and effectiveness of personal versus real loan guarantees.

1716 FRANCESCO FURLANETTO and ØRJAN ROBSTAD: Immigration and the macroeconomy: some new empirical evidence.

1717 ALBERTO FUERTES: Exchange rate regime and external adjustment: an empirical investigation for the U.S.

1718 CRISTINA GUILLAMÓN, ENRIQUE MORAL-BENITO and SERGIO PUENTE: High growth firms in employment and productivity: dynamic interactions and the role of financial constraints.

1719 PAULO SOARES ESTEVES and ELVIRA PRADES: On domestic demand and export performance in the euro area countries: does export concentration matter?

1720 LUIS J. ÁLVAREZ and ANA GÓMEZ-LOSCOS: A menu on output gap estimation methods.

1721 PAULA GIL, FRANCISCO MARTÍ, JAVIER J. PÉREZ, ROBERTO RAMOS and RICHARD MORRIS: The output effects of tax changes: narrative evidence from Spain.

1722 RICARDO GIMENO and ALFREDO IBÁÑEZ: The eurozone (expected) inflation: an option's eyes view.

1723 MIGUEL ANTÓN, SERGIO MAYORDOMO and MARÍA RODRÍGUEZ-MORENO: Dealing with dealers: sovereign CDS comovements.

\section{BANCODEESPAÑA}

$$
\text { Eurosistema }
$$

Unidad de Servicios Auxiliares

Alcalá, 48 - 28014 Madrid

E-mail: publicaciones@bde.es www.bde.es 